\title{
EFFECT OF DRYING METHODS ON THE QUALITY OF DRIED TOMATOES
}

\section{Reham S. Bakry ${ }^{1}$, El-Sayed G. Khater ${ }^{2 *^{*}}$, Adel H. Bahnasawy ${ }^{3}$ and Samir A. Ali ${ }^{3}$}

${ }^{1}$ MSc Stud., Ag. Eng. Dept., Fac. of Ag., Benha U., Egypt.

${ }^{2}$ Assoc. Prof., Ag. Eng. Dept., Fac. of Ag., Benha U., Egypt.

${ }^{3}$ Prof., Ag. Eng. Dept., Fac. of Ag., Benha U., Egypt.

* E-mail: alsayed.khater@fagr.bu.edu.eg

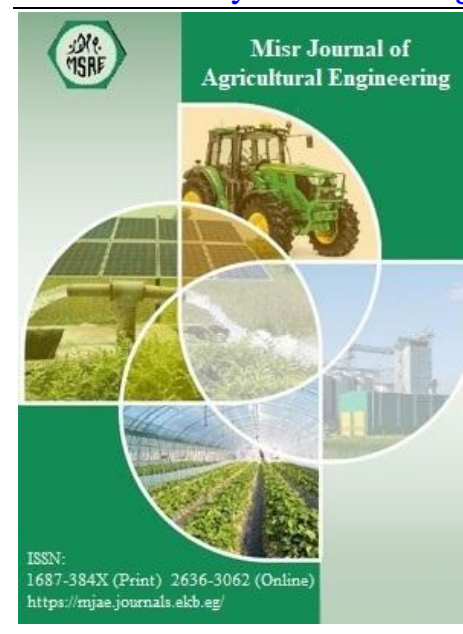

(C) Misr J. Ag. Eng. (MJAE)

Keywords:

Tomato, sun-drying, solar-

drying, oven-drying,

moisture content,

drying rate

\section{ABSTRACT}

The aim of this study is to investigate the effect of different drying the fruits tomato under different drying systems (sun, solar and oven), different chemical treatments (Citric acid $2 \%$ and without treatment) and different fruit tomato sizes (halffruit, quarter fruit, fruit strips of $7 \mathrm{~mm}$, fruit strips of $5 \mathrm{~mm}$ and fruit strips of $3 \mathrm{~mm}$ ) on the quality of dried tomato fruits. The results indicate that the accumulated weight loss of fruit tomato for fruit treated by citric acid 2\% lower than those the fruit without treatment. The accumulated weight loss of fruit tomato ranged from 2.00 to 94.73 $\%$ for all treatment. The highest values moisture content of fruits tomato were 870.08, 839.32, 819.15, 790.73 and $734.88 \%$ d.b. for half fruit, quarter fruit, fruit strips of $7 \mathrm{~mm}$, fruit strips of 5 mm and fruit strips of $3 \mathrm{~mm}$, respectively. The drying rate of fruits tomato ranged from 0.00 to $177.65,0.00$ to 71.03 and 0.001 to $163.36 \mathrm{~kg}_{\text {water }} / \mathrm{kg}_{\text {dry base }} . \mathrm{hr}$ for sun drying, solar drying and oven drying systems. The highest value of drying rate of fruits tomato was $177.65 \mathrm{~kg}_{\text {water }} / \mathrm{kg}_{\text {dry base. }}$. $\mathrm{hr}$ was found for $7 \mathrm{~mm}$ fruit strips with citric acid 2\% before drying for sun drying system. The sugar, ash and lycopene contents of fruit tomato for fruit treated by citric acid 2\% before drying higher than those the fruit without treatment.

\section{INTRODUCTION}

$\mathrm{T}$ lomato (Lycopersicon esculentum Mill) belongs to family "Solanaceae" and is a worldwide important agricultural commodity. In terms of area, tomato is the second horticultural product cultivated and the first in industrialized volume. Tomato is a climacteric fruit, having a short shelf-life under ambient storage conditions (Shahnawaz et al., 2012). The marketing of fresh tomato during the season is a great problem because of its short post-harvest life, which leads to high post-harvest losses (Jayathunge et al., 2012). Short postharvest life and inadequate processing facilities result in heavy revenue loss. Therefore, it is advantageous to develop a preservation method for tomatoes. Tomatoes are processed in a range of products, such as concentrated juice and pulp, which needs high cost technology for good quality products. Therefore, development of low-cost processing methodologies to produce shelf-stable convenience products is the prime requirement of the present competitive 
market. Drying is the most suitable method to fulfill the above requirements. Dried tomato products are used as important ingredients for pizza, various vegetables, spicy dishes, and the increasing interest in the antioxidant activity of lycopene as the most abundant carotenoid in tomatoes. Presence of lycopene promoted research activities on fresh tomatoes and tomato products (Zanoni et al., 1999). Drying is a form of preservation which is used in extending shelf life of produce, reducing risk of microbial spoilage due to reduction of water content to level where microbial growth no longer occurs. Drying tomatoes is a means of eliminating seasonal gluts and shortages, providing a technologically sound base for levelling out food surpluses and shortage within rural and urban area. Fresh tomatoes can be dried as halves, slices, quarters and powders. Once tomato is dried, it takes up a fraction of the space and can be used in all sorts of ways. It can be used in pizza toppings, snacks and other savory dishes (Lewicki et al., 2002). The quality of food can be seriously degraded if life is unprotected from rain, storm, windborne dirt, dust, and infestation by insects, rodents and other animals, so sometimes production becomes inedible. The drying process can be conducted by using several solar drying methods (Sacilik et al., 2006 and Abd El-Haq et al., 2020). Solar dryers can cost effectively because relatively unskilled village artisans can construct, operate and maintain the dryers at minimum cost and locally available materials can be used for the construction (Mumba, 1995). Ekechukwu and Norton (1999), in reviewing the various designs of solarenergy drying systems, classified them with respect to their operating temperature ranges, heat supply modes and sources, operational modes and structural modes as well. Natural circulation and forced-convection solar dryers are the two main groups that were identified (Vlachos et al., 2002). The drying characteristics of tomato and their mathematical drying model are still being developed. Thin layer drying equations are used to estimate drying time of several products and also to generalize drying curves.

To keep the tomato quality, prolong shelf life and decrease losses, several methods of drying are required, therefore, the main aim of this work is to study the effect of drying methods, pretreatments of fruit and shapes of fruit on the tomato quality and shelf life.

\section{MATERIALS AND METHODS}

The experiment was carried out at Agricultural and Bio-Systems Engineering Department, Faculty of Agriculture Moshtohor, Benha University, Egypt (latitude $30^{\circ} 21^{`} \mathrm{~N}$ and $31^{\circ} 13^{`} \mathrm{E}$ ). During the period of June and July, 2018 season.

\subsection{Materials:}

The fresh tomato was brought from the Faculty of Agriculture Farm, Moshtohor, Benha University after harvesting for primary analysis.

\subsubsection{Drying systems:}

The tomato fruit were dried using different systems as follows:-

\section{Sun-drying:}

Tomato fruits were folded into a thin sheet of paper and placed on a flat plate in direct sunlight. Tray with a dimension of ( $0.8 \mathrm{~m}$ long, $0.6 \mathrm{~m}$ wide and $0.1 \mathrm{~m}$ high).

\section{Solar drying:}

Fig. (1) illustrates the hybrid-solar drying system description. It shows the system which consists of solar collector, drying chamber, trays and blower. 
The solar collector consists of three major components, namely: The glass cover has dimensions of $4.0 \mathrm{~m}$ long, $1.0 \mathrm{~m}$ width and $5.5 \mathrm{~mm}$ thickness. The cover is fixed on a wooden frame with a thickness of $10 \mathrm{~cm}$. It is divided into two lanes, $50 \mathrm{~cm}$ wide each. The absorber plate is made from corrugated black aluminum plate. It insulated with a thermal glass wool with a $5.0 \mathrm{~cm}$ thickness. The drying chamber has a length of $1.0 \mathrm{~m}$, width of $0.75 \mathrm{~m}$ and height of $1.0 \mathrm{~m}$. It is made of galvanized steel ( $5 \mathrm{~mm}$ thickness). The inner surface of drying chamber is covered an insulated materials to reduce heat loss from the walls. The trays are made of stainless steel and have a length of $0.90 \mathrm{~m}$, width of $0.65 \mathrm{~m}$ and height of $0.25 \mathrm{~m}$. They have perforated bottom which allows heated air to pass through products. Two air blowers were used to force and recirculate the drying air to the drying chamber (Model C.C.P. Parma - Flow Rate $6.6 \mathrm{~m}^{3} \mathrm{~h}^{-1}$ RPM 2800 - Power 150 W, 220V 50Hz, Italy).
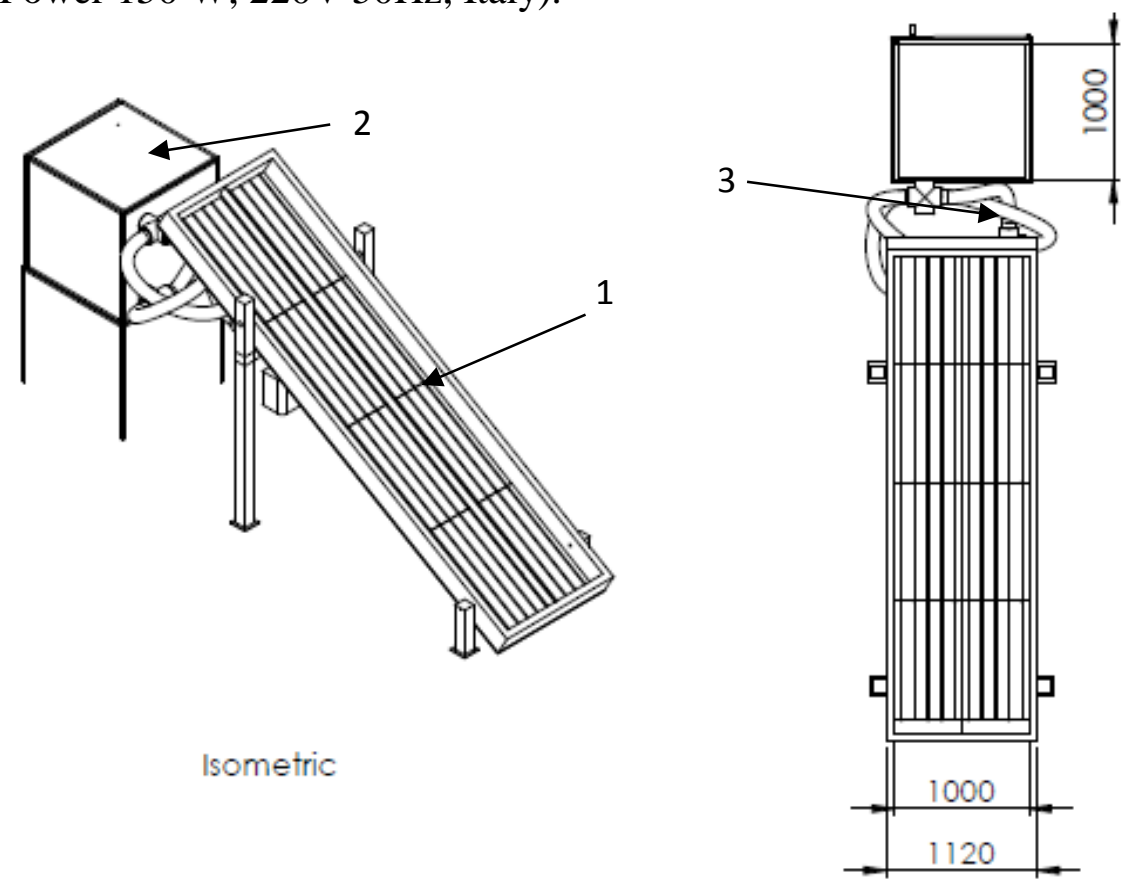

Top View
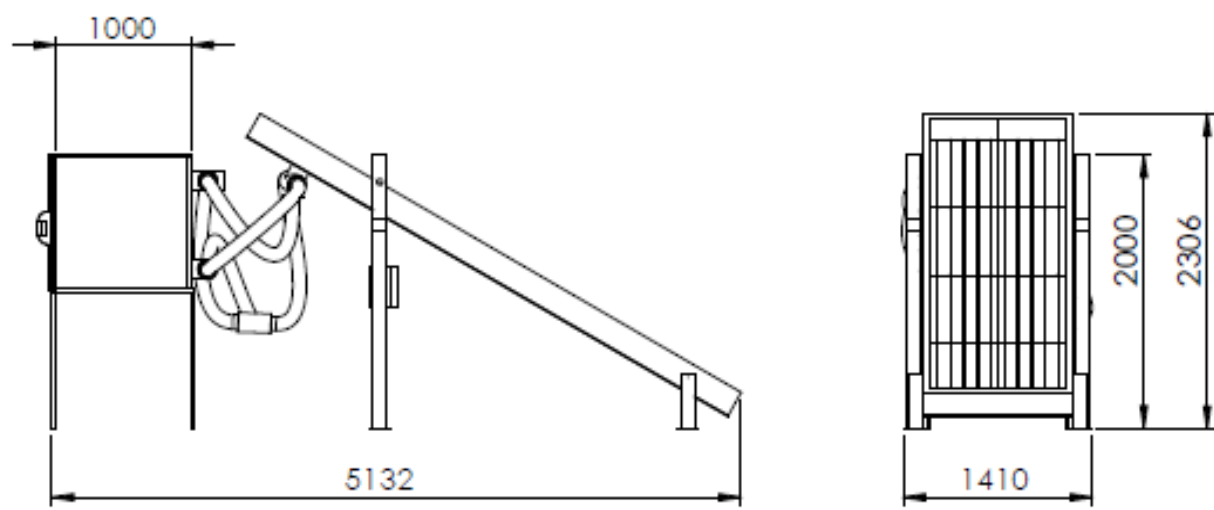

Left View

Front View

1: solar collector

2: drying chamber

3: blower

Fig. (1): Isometric, top, left and front view for the solar dryer. 
The dryer uses a chamber burner system in which heat is being produced. The burner incorporates switches with a sparking mechanism that ignites the gas when it is fed from the gas bottle.

\section{Oven-drying:}

Fruits tomato were spread evenly on baking sheets and placed in conventional laboratory oven (Fisher Scientific Isotemp Oven, Model 655F Cat. No. 13-245-655, Fisher Scientific, Toronto, Ontario, Canada).

\subsection{Methods:}

\subsubsection{Treatments:}

In this study, tomatoes were cut into halves, quarters, and strips with 3, 5 and $7 \mathrm{~mm}$ thickness. Samples were divided into 2 parts, one of them treated with citric acid $2 \%$ before drying and the other part left without chemical treatment. Table (1) shows the experimental design for drying tomato.

Table (3.4): The experimental design.

\begin{tabular}{|c|c|c|}
\hline Variables & Levels & Variables Levels \\
\hline \multirow{3}{*}{ Drying system } & \multirow{3}{*}{3} & Sun drying \\
\hline & & Solar drying \\
\hline & & Oven drying \\
\hline \multirow{2}{*}{ Pre-treatment } & \multirow{2}{*}{2} & Citric acid $2 \%$ \\
\hline & & Without chemical \\
\hline \multirow{5}{*}{ Tomato fruit size } & \multirow{5}{*}{5} & Half \\
\hline & & Quarter \\
\hline & & $3 \mathrm{~mm}$ \\
\hline & & $5 \mathrm{~mm}$ \\
\hline & & $7 \mathrm{~mm}$ \\
\hline
\end{tabular}

\subsubsection{Measurements:}

The mass was measured by electric digital balance (Model HG - 5000 - Range 0 - $5000 \mathrm{~g} \pm$ $0.01 \mathrm{~g}$, Japan) daily for sun drying methods and hourly for solar and oven drying methods. Temperature and relative humidity were recorded by using a HOBO Data Logger (Model HOBO U12 Temp/RH/Light - Range -20 to $70{ }^{\circ} \mathrm{C}$ and 5 to $95 \% \mathrm{RH}$, USA) every hour. Total content of macro elements were evaluated after being digested according to Chapman and Partt (1961). Nitrogen was determined by Kjeldahl digestion apparatus (Bremmer and Mulvaney, 1982). Potassium, Calcium and magnesium were determined by Photofatometer (Model Jenway PFP7 - Range 0 - $160 \mathrm{mmol} \mathrm{L}^{-1}$, USA) and phosphorus (P) was determined colorimetrically following the Murphy and Riley (1962) method.

\subsubsection{Calculations:}

- Moisture content:

Moisture content of the fresh and dried fruit tomato was determined using conventional laboratory oven kept at $105{ }^{\circ} \mathrm{C}$ until constant weight was reached (ASAE, 1998). Triplicate determinations were made and the moisture content calculated as the following equation:

$$
M C=\frac{\mathrm{M}_{\text {wet }}-M_{d r y}}{\mathrm{M}_{\mathrm{dry}}} \times 100
$$


Where:

$\mathrm{MC}$ is the moisture content, $\%$ dry base (d.b.)

$\mathrm{M}_{\text {wet }}$ is the wet mass of samples, $\mathrm{g}$

$\mathrm{M}_{\text {dry }}$ is the dry mass of samples, $\mathrm{g}$

- Drying rate:

The drying rate (DR) of fruit tomato was calculated using the following equation:

$$
D R=\frac{\mathrm{M}_{\mathrm{t}+\mathrm{dt}}-M_{t}}{\mathrm{dt}}
$$

Where:

$\mathrm{DR}$ is the drying rate, $\left(\mathrm{kg}_{\text {water }} / \mathrm{kg}_{\text {dry base }} \cdot \mathrm{hr}\right)$

$\mathrm{M}_{\mathrm{t}}$ is the moisture content at any time t, \% d.b.

$\mathrm{M}_{\mathrm{t}+\mathrm{dt}}$ is the moisture content at $\mathrm{t}+\mathrm{dt}$, \% d.b.

\subsection{Weight loss:}

\section{RESULTS AND DISCUSSION}

\subsubsection{Sun drying system:}

Fig. (3) shows the accumulated weight loss of fruit tomato that dried under sun drying system at different chemical treatments (citric acid $2 \%$ and without treatment) and different fruit tomato sizes (half fruit, quarter fruit, fruit strips of $7 \mathrm{~mm}$, fruit strips of $5 \mathrm{~mm}$ and fruit strips of $3 \mathrm{~mm}$ ) during experimental period. The results indicate that the accumulated weight loss of fruit tomato increases with increasing drying period. It could be seen that the accumulated weight loss of tomato increased from 31.58 to 86.71 and 29.57 to $85.96 \%$, when the drying period increased from 1 to 10 days for the tomato treated with citric acid $2 \%$ before drying and without treatment, respectively, for half fruit tomato size. It increased from 32.84 to 86.81 and 30.67 to $85.35 \%$, when the drying period increased from 1 to 7 days for the tomato treated with citric acid $2 \%$ before drying and without treatment, respectively, for quarter fruit tomato size. It increased from 33.36 to 86.29 and 31.18 to $83.98 \%$, when the drying period increased from 1 to 4 days for the tomato treated with citric acid $2 \%$ before drying and without treatment, respectively, for fruit strips of $7 \mathrm{~mm}$ size. It increased from 36.34 to 86.01 and 32.42 to $84.56 \%$, when the drying period increased from 1 to 4 days for the tomato treated with citric acid $2 \%$ before drying and without treatment, respectively, for fruit strips of $5 \mathrm{~mm}$ size. It increased from 37.33 to 84.96 and 32.62 to $82.84 \%$, when the drying period increased from 1 to 4 days for the tomato treated with citric acid $2 \%$ before drying and without treatment, respectively, for fruit strips $3 \mathrm{~mm}$ size.

The results also indicate that the accumulated weight loss of fruit tomato for fruit treated by citric acid $2 \%$ before drying lower than those the fruit without treatment. It could be seen that the accumulated weight loss of fruit tomato was 86.71 and 85.96, 86.81 and 85.35, 86.29 and 83.98, 86.01 and 84.56 and 84.96 and $82.84 \%$ for the untreated tomatoes and for the treated with citric acid $2 \%$ for half fruit, quarter fruit, fruit strips of $7 \mathrm{~mm}$, fruit strips of $5 \mathrm{~mm}$ and fruit strips of $3 \mathrm{~mm}$ sizes, respectively, at the average temperature of $35.5 \pm 3.7^{\circ} \mathrm{C}$ and relative humidity of $57.5 \pm 2.0 \%$.

Regression analysis was carried out to obtain a relationship between the accumulated weight loss of tomato fruit dried on sun drying system as dependent variable and different pre-treatment before drying, tomato fruit sizes and experimental period as independent variables. The best fit 
for this relationship is presented in the following equation. The constants of these equations and coefficient of determination are listed in table (2).

$$
W L=a+b \operatorname{lnt}
$$

Where:

WL is the accumulated weight loss, $\%$

$\mathrm{t}$ is the experimental period, day
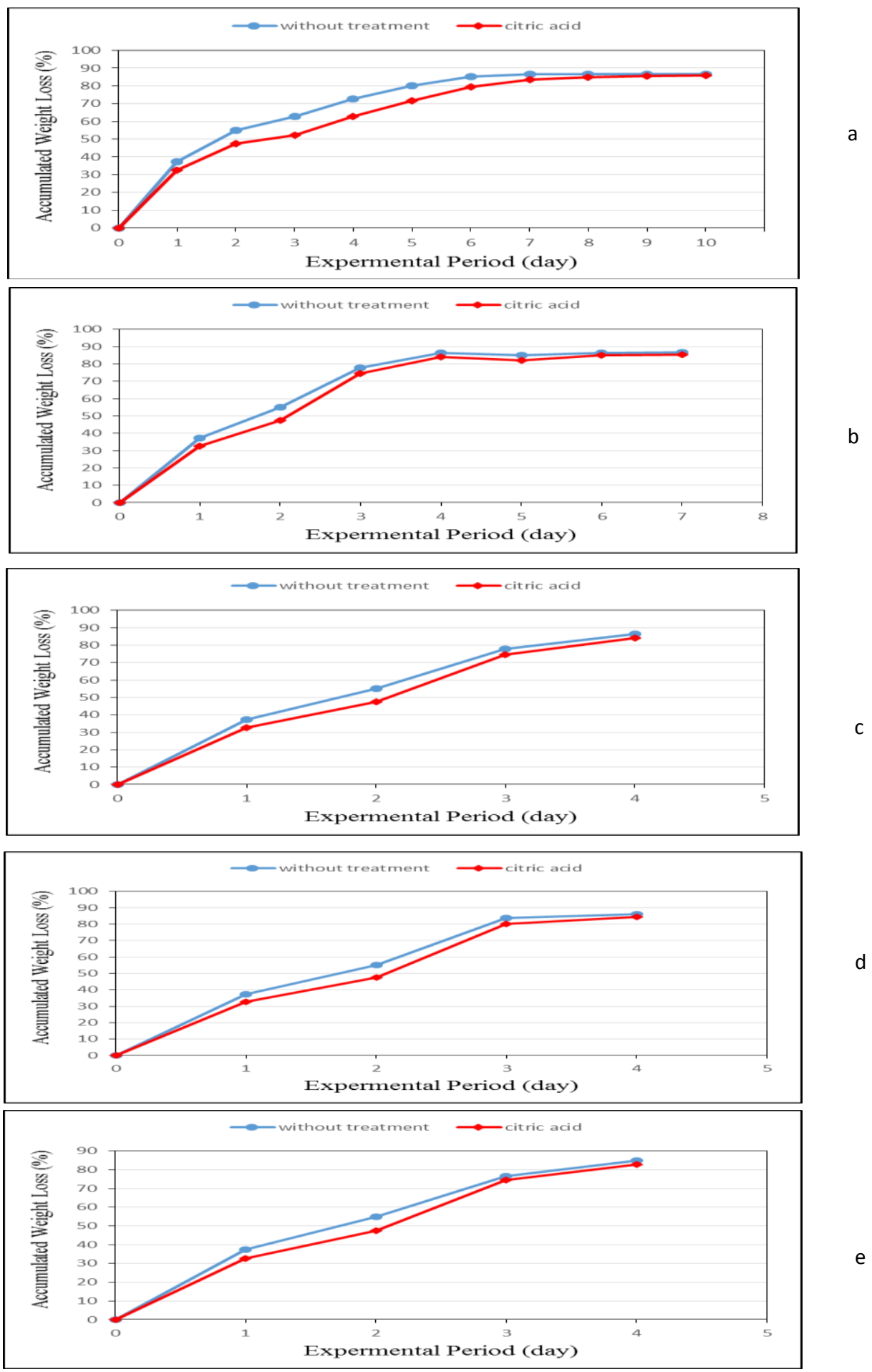

a: half fruit, b: quarter fruit, c: strips $7 \mathrm{~mm}$, d: strips $5 \mathrm{~mm}$ e: strips $3 \mathrm{~mm}$

Fig. (3): The accumulated weight loss of fruit tomato at different sizes for sun drying system during experimental period. 
Table (2): The constants $\mathrm{a}, \mathrm{b}$ and coefficient of determination for accumulated weight loss at the different tomato fruit sizes and the different pre-treatment before drying.

\begin{tabular}{|l|c|c|c|c|c|c|}
\hline \multirow{2}{*}{$\begin{array}{l}\text { Tomato } \\
\text { fruit size }\end{array}$} & \multicolumn{3}{|c|}{ Without treatment } & \multicolumn{3}{c|}{ Citric acid 2\% treatment } \\
\cline { 2 - 3 } & \multicolumn{2}{|c|}{ Constants } & \multirow{2}{*}{$\mathrm{R}^{2}$} & \multicolumn{2}{c|}{ Constants } & \multirow{2}{*}{$\mathrm{R}^{2}$} \\
\cline { 2 - 3 } \cline { 5 - 7 } & $\mathrm{A}$ & $\mathrm{b}$ & & $\mathrm{a}$ & $\mathrm{b}$ & \\
\hline Half & -27.04 & 38.17 & 0.881 & -26.44 & 36.98 & 0.876 \\
\hline Quarter & -20.36 & 38.54 & 0.926 & -19.74 & 37.06 & 0.926 \\
\hline $7 \mathrm{~mm}$ & -19.01 & 36.55 & 0.909 & -21.74 & 36.59 & 0.891 \\
\hline $5 \mathrm{~mm}$ & 2.81 & 36.69 & 0.973 & 1.55 & 36.88 & 0.979 \\
\hline $3 \mathrm{~mm}$ & 9.14 & 35.49 & 0.964 & 5.18 & 35.95 & 0.979 \\
\hline
\end{tabular}

\subsubsection{Solar drying system:}

Fig. (4) shows the accumulated weight loss of fruit tomato that dried under solar drying system at different chemical treatments (citric acid $2 \%$ and without treatment) and different fruit tomato sizes (half fruit, quarter fruit, fruit strips of $7 \mathrm{~mm}$, fruit strips of $5 \mathrm{~mm}$ and fruit strips of $3 \mathrm{~mm}$ ) during experimental period. The results indicate that the accumulated weight loss of fruit tomato increases with increasing drying period. It could be seen that the accumulated weight loss of tomato increased from 2.24 to 91.15 and 2.00 to $87.62 \%$, when the drying period increased from 1 to 17 hours for the tomato treated with citric acid $2 \%$ before drying and without treatment, respectively, for half fruit tomato size. It increased from 8.79 to 90.06 and 7.56 to $86.40 \%$, when the drying period increased from 1 to 17 hours for the tomato treated with citric acid $2 \%$ before drying and without treatment, respectively, for quarter fruit tomato size. It increased from 9.89 to 90.08 and 6.39 to $88.83 \%$, when the drying period increased from 1 to 17 hours for the tomato treated with citric acid $2 \%$ before drying and without treatment, respectively, for fruit strips of $7 \mathrm{~mm}$ size. It increased from 26.48 to 89.82 and 25.43 to 86.79 $\%$, when the drying period increased from 1 to 11 hours for the tomato treated with citric acid $2 \%$ before drying and without treatment, respectively, for fruit strips of $5 \mathrm{~mm}$ size. It increased from 34.79 to 91.69 and 28.45 to $89.44 \%$, when the drying period increased from 1 to 11 hours for the tomato treated with citric acid $2 \%$ before drying and without treatment, respectively, for fruit strips of $3 \mathrm{~mm}$ size.

The results also indicate that the accumulated weight loss of fruit tomato for fruit treated by citric acid $2 \%$ before drying lower than those the fruit without treatment. It could be seen that the accumulated weight loss of fruit tomato was 91.15 and 87.62, 90.06 and 86.40, 90.08 and $88.83,89.82$ and 86.79 and 91.69 and $89.44 \%$ for the untreated tomatoes and for the treated with citric acid $2 \%$ for half fruit, quarter fruit, fruit strips of $7 \mathrm{~mm}$, fruit strips of $5 \mathrm{~mm}$ and fruit strips of $3 \mathrm{~mm}$ sizes, respectively, at the average temperature of $51.0 \pm 9.0^{\circ} \mathrm{C}$ and relative humidity of $40.0 \pm 13.0 \%$.

Statistical analysis was carried out to obtain a relationship between the accumulated weight loss of tomato fruit dried on solar dryer as dependent variable and different pre-treatment before drying, tomato fruit sizes and experimental period as independent variables. The best fit for this relationship is presented in the following equation. The constants of these equations and coefficient of determination are listed in table (3).

$$
W L=a+b \ln t
$$




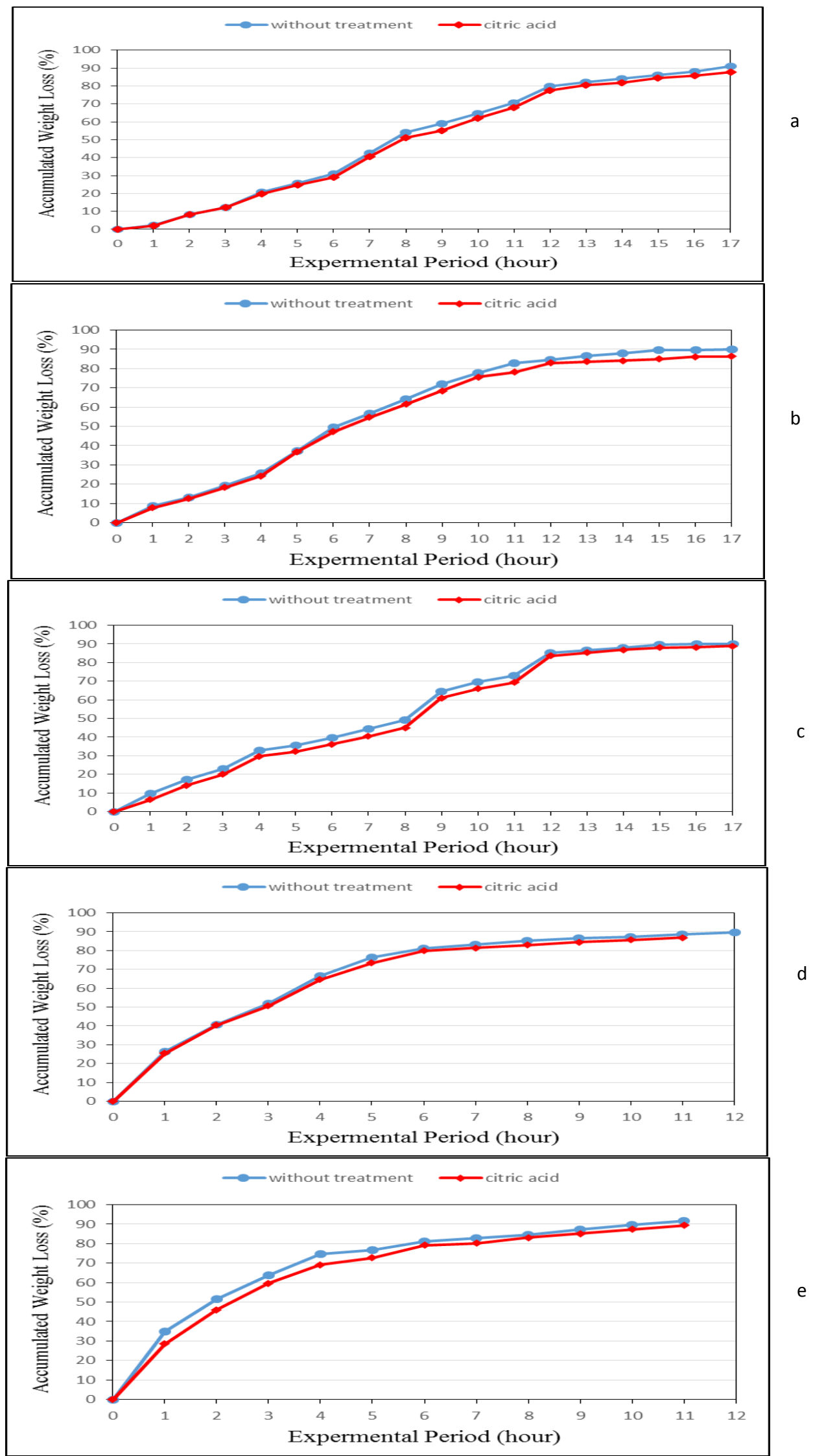

a: half fruit, b: quarter fruit, c: strips $7 \mathrm{~mm}$, d: strips $5 \mathrm{~mm}$ e: strips $3 \mathrm{~mm}$

Fig. (4): The accumulated weight loss of fruit tomato at different sizes for solar drying system during experimental period. 
Table (3): The constants $\mathrm{a}, \mathrm{b}$ and coefficient of determination for accumulated weight loss at the different tomato fruit sizes and the different pre-treatment before drying.

\begin{tabular}{|l|c|c|c|c|c|c|}
\hline \multirow{2}{*}{$\begin{array}{l}\text { Tomato } \\
\text { fruit size }\end{array}$} & \multicolumn{3}{|c|}{ Without treatment } & \multicolumn{3}{c|}{ Citric acid 2\% treatment } \\
\cline { 2 - 3 } & \multicolumn{2}{|c|}{ Constants } & \multirow{2}{*}{$\mathrm{R}^{2}$} & \multicolumn{2}{c|}{ Constants } & \multirow{2}{*}{$\mathrm{R}^{2}$} \\
\cline { 2 - 3 } & $\mathrm{A}$ & $\mathrm{b}$ & & $\mathrm{a}$ & $\mathrm{b}$ & \\
\hline Half & 7.76 & 37.04 & 0.955 & 3.26 & 37.00 & 0.986 \\
\hline Quarter & 3.79 & 44.12 & 0.972 & 1.76 & 43.77 & 0.977 \\
\hline $7 \mathrm{~mm}$ & -2.00 & 54.82 & 0.993 & -3.04 & 52.72 & 0.979 \\
\hline $5 \mathrm{~mm}$ & -1.20 & 55.78 & 0.982 & -3.00 & 54.21 & 0.968 \\
\hline $3 \mathrm{~mm}$ & -0.27 & 53.33 & 0.996 & -2.31 & 51.99 & 0.981 \\
\hline
\end{tabular}

\subsubsection{Oven drying system:}

Fig. (5) shows the accumulated weight loss of fruit tomato that dried under oven drying system at different chemical treatments (citric acid $2 \%$ and without treatment) and different fruit tomato sizes (half fruit, quarter fruit, fruit strips of $7 \mathrm{~mm}$, fruit strips of $5 \mathrm{~mm}$ and fruit strips of $3 \mathrm{~mm}$ ) during experimental period. The results indicate that the accumulated weight loss of fruit tomato increases with increasing drying period. It could be seen that the accumulated weight loss of tomato increased from 12.57 to 94.79 and 11.01 to $93.40 \%$, when the drying period increased from 1 to 11 hours for the tomato treated with citric acid $2 \%$ before drying and without treatment, respectively, for half fruit tomato size. It increased from 18.56 to 94.49 and 16.68 to $92.52 \%$, when the drying period increased from 1 to 8 hours for the tomato treated with citric acid $2 \%$ before drying and without treatment, respectively, for quarter fruit tomato size. It increased from 54.09 to 93.45 and 46.20 to $90.41 \%$, when the drying period increased from 1 to 5 hours for the tomato treated with citric acid $2 \%$ before drying and without treatment, respectively, for fruit strips of $7 \mathrm{~mm}$ size. It increased from 62.99 to 95.85 and 60.40 to 93.57 $\%$, when the drying period increased from 1 to 4 hours for the tomato treated with citric acid $2 \%$ before drying and without treatment, respectively, for fruit strips of $5 \mathrm{~mm}$ size. It increased from 83.32 to 94.73 and 80.37 to $91.65 \%$, when the drying period increased from 1 to 4 hours for the tomato treated with citric acid $2 \%$ before drying and without treatment, respectively, for fruit strips of $3 \mathrm{~mm}$ size.

The results also indicate that the accumulated weight loss of fruit tomato for fruit treated by citric acid $2 \%$ before drying lower than those the fruit without treatment. It could be seen that the accumulated weight loss of fruit tomato was 94.79 and $93.40,94.49$ and $92.52,93.45$ and 90.41, 95.85 and 93.57 and 94.73 and $91.65 \%$ for the untreated tomatoes and for the treated with citric acid $2 \%$ for half fruit, quarter fruit, fruit strips of $7 \mathrm{~mm}$, fruit strips of $5 \mathrm{~mm}$ and fruit strips of $3 \mathrm{~mm}$ sizes, respectively at temperature of $65^{\circ} \mathrm{C}$.

The results also indicate that the shorter drying period (4 hours) was occurred under the oven drying system due to the higher temperature $\left(65^{\circ} \mathrm{C}\right)$ and lower relative humidity $(10 \%)$. Meanwhile, the longer drying period (17 days) was occurred under the sun drying system due to the lower temperature $\left(30.5\right.$ to $\left.35.8^{\circ} \mathrm{C}\right)$ and higher relative humidity $(51.92$ to $61.44 \%)$. The trend of these results agreed with those obtained by Khater and Bahnasawy (2017) and Abd El-Haq et al. (2020). 


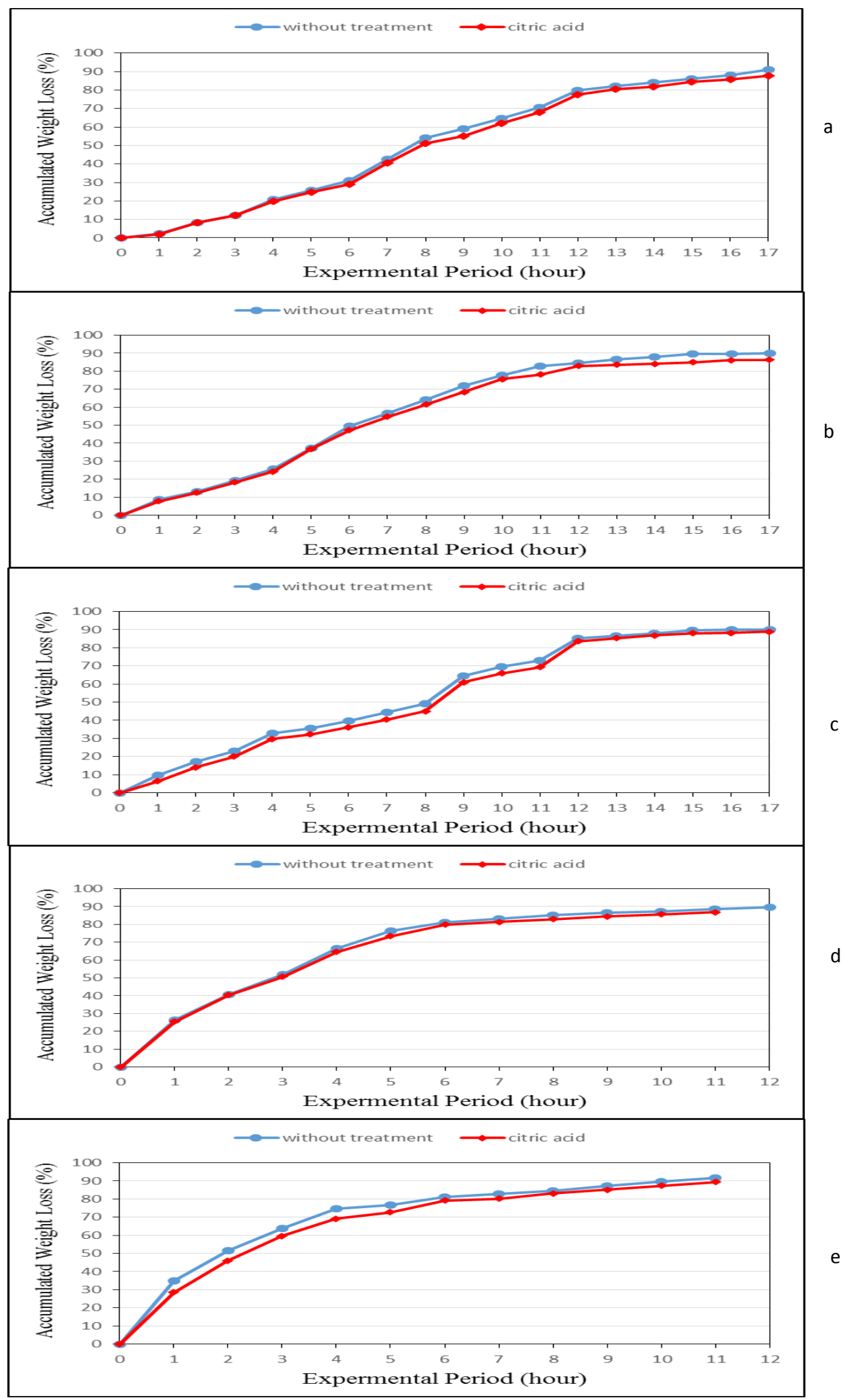

a: half fruit, b: quarter fruit, c: strips $7 \mathrm{~mm}$, d: strips $5 \mathrm{~mm}$ e: strips $3 \mathrm{~mm}$

Fig. (5): The accumulated weight loss of fruit tomato at different sizes for oven drying system during experimental period.

Statistical analysis was carried out to obtain a relationship between the accumulated weight loss of tomato fruit dried on oven drying system as dependent variable and different pre-treatment before drying, tomato fruit sizes and experimental period as independent variables. The best fit 
for this relationship is presented in the following equation. The constants of these equations and coefficient of determination are listed in table (4).

$$
W L=a+b \ln t
$$

Table (4): The constants $a, b$ and coefficient of determination for accumulated weight loss at the different tomato fruit sizes and the different pre-treatment before drying.

\begin{tabular}{|l|c|c|c|c|c|c|}
\hline \multirow{2}{*}{$\begin{array}{l}\text { Tomato } \\
\text { fruit size }\end{array}$} & \multicolumn{3}{|c|}{ Without treatment } & \multicolumn{3}{c|}{ Citric acid 2\% treatment } \\
\cline { 2 - 3 } & \multicolumn{2}{|c|}{ Constants } & \multicolumn{2}{c|}{ Constants } & \multirow{2}{*}{$\mathrm{R}^{2}$} \\
\cline { 2 - 3 } \cline { 5 - 6 } & $\mathrm{a}$ & $\mathrm{b}$ & & $\mathrm{a}$ & $\mathrm{b}$ & \\
\hline Half & -8.06 & 43.76 & 0.971 & -8.15 & 43.40 & 0.969 \\
\hline Quarter & -5.00 & 50.56 & 0.966 & -5.41 & 49.27 & 0.963 \\
\hline $7 \mathrm{~mm}$ & 7.11 & 60.94 & 0.937 & 4.16 & 57.94 & 0.967 \\
\hline $5 \mathrm{~mm}$ & 5.21 & 70.76 & 0.968 & 4.83 & 69.55 & 0.968 \\
\hline $3 \mathrm{~mm}$ & 17.74 & 57.52 & 0.896 & 17.11 & 55.81 & 0.898 \\
\hline
\end{tabular}

\subsection{Moisture content:}

\subsubsection{Sun drying system:}

Fig. (6) shows the moisture content of fruit tomato that dried under sun drying system at different chemical treatments (citric acid $2 \%$ and without treatment) and different fruit tomato sizes (half fruit, quarter fruit, fruit strips of $7 \mathrm{~mm}$, fruit strips of $5 \mathrm{~mm}$ and fruit strips of $3 \mathrm{~mm}$ ) during experimental period. The results indicate that the moisture content of fruit tomato decreases with increasing drying period for all drying systems. It could be seen that the moisture content of tomato decreased from 854.66 to 0.54 and 870.08 to $5.84 \%$ d.b., when the drying period increased from 1 to 10 days for the tomato treated with citric acid $2 \%$ before drying and without treatment, respectively, for half fruit tomato size. It decreased from 735.31 to 0.81 and 754.54 to $0.88 \%$ d.b., when the drying period increased from 1 to 7 days for the tomato treated with citric acid $2 \%$ before drying and without treatment, respectively, for quarter fruit tomato size.

The moisture content decreased from 701.22 to 3.34 and 718.32 to $7.74 \%$ d.b., when the drying period increased from 1 to 4 days for the tomato treated with citric acid $2 \%$ before drying and without treatment, respectively, for fruit strips of $7 \mathrm{~mm}$ size. It decreased from 561.95 to 1.01 and 606.41 to $9.62 \%$ d.b., when the drying period increased from 1 to 4 days for the tomato treated with citric acid $2 \%$ before drying and without treatment, respectively, for fruit strips of $5 \mathrm{~mm}$ size. It decreased from 551.34 to 0.64 and 567.41 to $0.54 \%$ d.b., when the drying period increased from 1 to 4 days for the tomato treated with citric acid $2 \%$ before drying and without treatment, respectively, for fruit strips of $3 \mathrm{~mm}$ size.

The results also indicate that the moisture content of fruit tomato for fruit treated by citric acid $2 \%$ before drying higher than those the fruit without treatment. It could be seen that the moisture content of fruit tomato was 854.66 and 870.08, 735.31 and 754.54, 701.22 and 718.32, 561.95 and 606.41 and 551.34 and $567.41 \%$ d.b. for the untreated tomatoes and for the treated with citric acid $2 \%$ for half fruit, quarter fruit, fruit strips of $7 \mathrm{~mm}$, fruit strips of $5 \mathrm{~mm}$ and fruit strips of $3 \mathrm{~mm}$ sizes, respectively.

Statistical analysis was carried out to obtain a relationship between the moisture content of fruit tomato of tomato fruit dried on sun drying system as dependent variable and different pretreatment before drying, tomato fruit sizes and experimental period as independent variables. 
The best fit for this relationship is presented in the following equation. The constants of these equations and coefficient of determination are listed in table (5).

$$
M C=a+b \ln t
$$

Where:

$\mathrm{MC}$ is the moisture content. \% d.b.

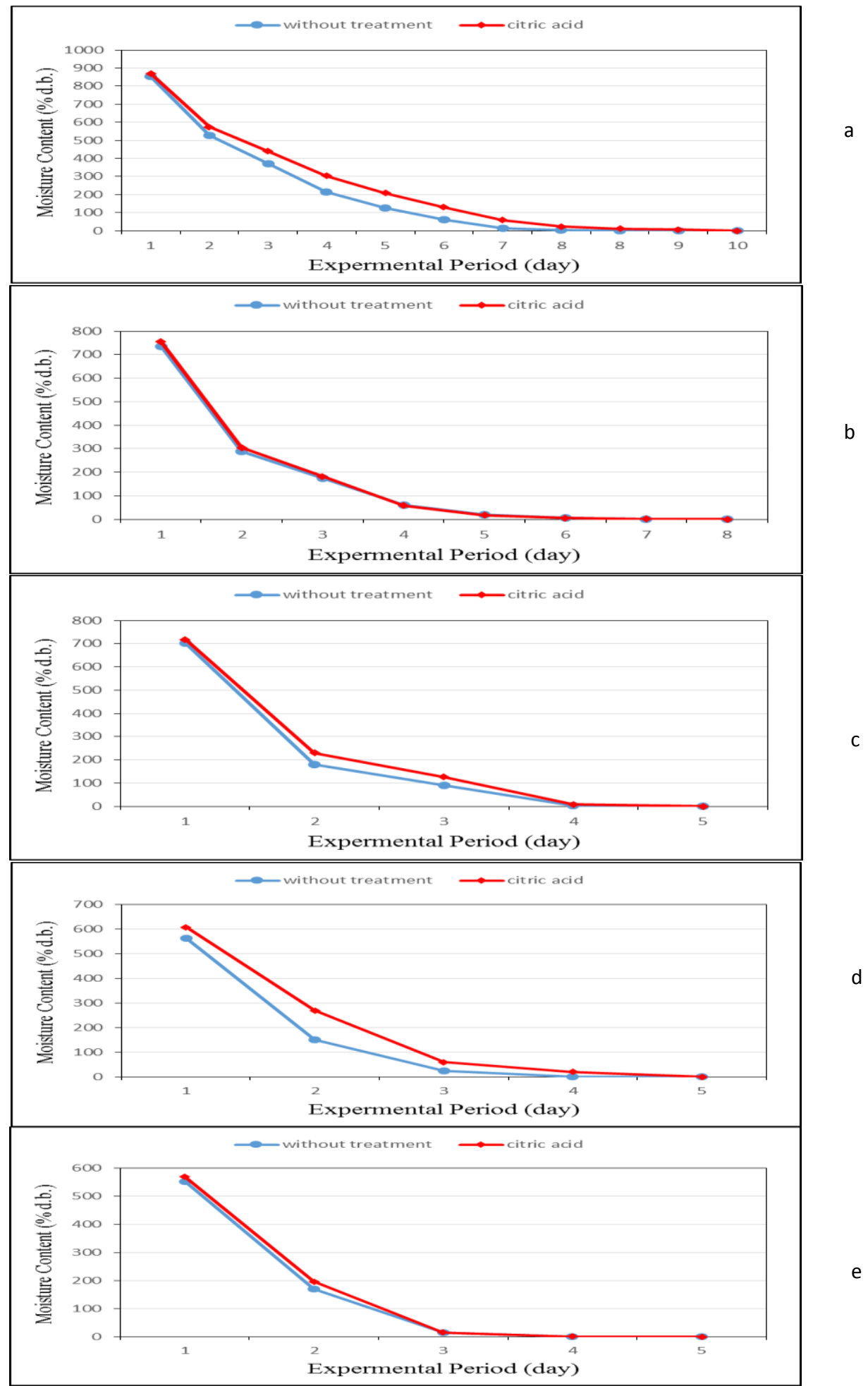

a: half fruit, b: quarter fruit, c: strips $7 \mathrm{~mm}$, d: strips $5 \mathrm{~mm}$ e: strips $3 \mathrm{~mm}$

Fig. (6): The moisture content of fruit tomato at different sizes for sun drying system during experimental period. 
Table (5): The constants $\mathrm{a}, \mathrm{b}$ and coefficient of determination for moisture content at the different tomato fruit sizes and the different pre-treatment before drying.

\begin{tabular}{|l|c|c|c|c|c|c|}
\hline \multirow{2}{*}{$\begin{array}{l}\text { Tomato } \\
\text { fruit size }\end{array}$} & \multicolumn{3}{|c|}{ Without treatment } & \multicolumn{3}{c|}{ Citric acid 2\% treatment } \\
\cline { 2 - 3 } & \multicolumn{2}{|c|}{ Constants } & \multirow{2}{*}{$\mathrm{R}^{2}$} & \multicolumn{2}{c|}{ Constants } & \multirow{2}{*}{$\mathrm{R}^{2}$} \\
\cline { 2 - 3 } & $\mathrm{A}$ & $\mathrm{B}$ & & $\mathrm{a}$ & $\mathrm{b}$ & \\
\hline Half & 799.33 & -385.42 & 0.970 & 854.21 & -391.75 & 0.992 \\
\hline Quarter & 636.59 & -371.91 & 0.920 & 656.40 & -384.00 & 0.924 \\
\hline $7 \mathrm{~mm}$ & 643.36 & -503.24 & 0.932 & 674.35 & -508.48 & 0.959 \\
\hline $5 \mathrm{~mm}$ & 516.51 & -418.29 & 0.935 & 589.60 & -442.27 & 0.979 \\
\hline $3 \mathrm{~mm}$ & 514.23 & -415.73 & 0.948 & 536.04 & -429.63 & 0.958 \\
\hline
\end{tabular}

\subsubsection{Solar drying system:}

Fig. (7) shows the moisture content of fruit tomato that dried under solar drying system at different chemical treatments (citric acid $2 \%$ and without treatment) and different fruit tomato sizes (half fruit, quarter fruit, fruit strips of $7 \mathrm{~mm}$, fruit strips of $5 \mathrm{~mm}$ and fruit strips of $3 \mathrm{~mm}$ ) during experimental period. The results indicate that the moisture content of fruit tomato decreases with increasing drying period for all drying systems. It could be seen that the moisture content of tomato decreased from 853.55 to 26.79 and 869.96 to $45.44 \%$ d.b., when the drying period increased from 1 to 17 hours for the tomato treated with citric acid $2 \%$ before drying and without treatment, respectively, for half fruit tomato size. It decreased from 780.45 to 48.67 and 835.67 to $56.12 \%$ d.b., when the drying period increased from 1 to 17 hours for the tomato treated with citric acid $2 \%$ before drying and without treatment, respectively, for quarter fruit tomato size. It decreased from 799.19 to 13.08 and 918.15 to $21.09 \%$ d.b., when the drying period increased from 1 to 17 hours for the tomato treated with citric acid $2 \%$ before drying and without treatment, respectively, for fruit strips of $7 \mathrm{~mm}$ size. It decreased from 764.96 to 4.98 and 790.73 to $9.36 \%$ d.b., when the drying period increased from 1 to 11 hours for the tomato treated with citric acid $2 \%$ before drying and without treatment, respectively, for fruit strips of $5 \mathrm{~mm}$ size. It decreased from 664.24 to 1.35 and 734.88 to $1.62 \%$ d.b., when the drying period increased from 1 to 11 hours for the tomato treated with citric acid $2 \%$ before drying and without treatment, respectively, for fruit strips of $3 \mathrm{~mm}$ size.

The results also indicate that the moisture content of fruit tomato for fruit treated by citric acid $2 \%$ before drying higher than those the fruit without treatment. It could be seen that the moisture content of fruit tomato was 853.55 and 869.96, 780.45 and 835.67, 799.19 and 819.15, 764.98 and 790.73 and 664.24 and $734.88 \%$ d.b. for the untreated tomatoes and for the treated with citric acid $2 \%$ for half fruit, quarter fruit, fruit strips of $7 \mathrm{~mm}$, fruit strips of $5 \mathrm{~mm}$ and fruit strips of $3 \mathrm{~mm}$ sizes, respectively.

Statistical analysis was carried out to obtain a relationship between the moisture content of fruit tomato of tomato fruit dried on solar drying system as dependent variable and different pretreatment before drying, tomato fruit sizes and experimental period as independent variables. The best fit for this relationship is presented in the following equation. The constants of these equations and coefficient of determination are listed in table (6).

$$
M C=a+b \operatorname{lnt}
$$




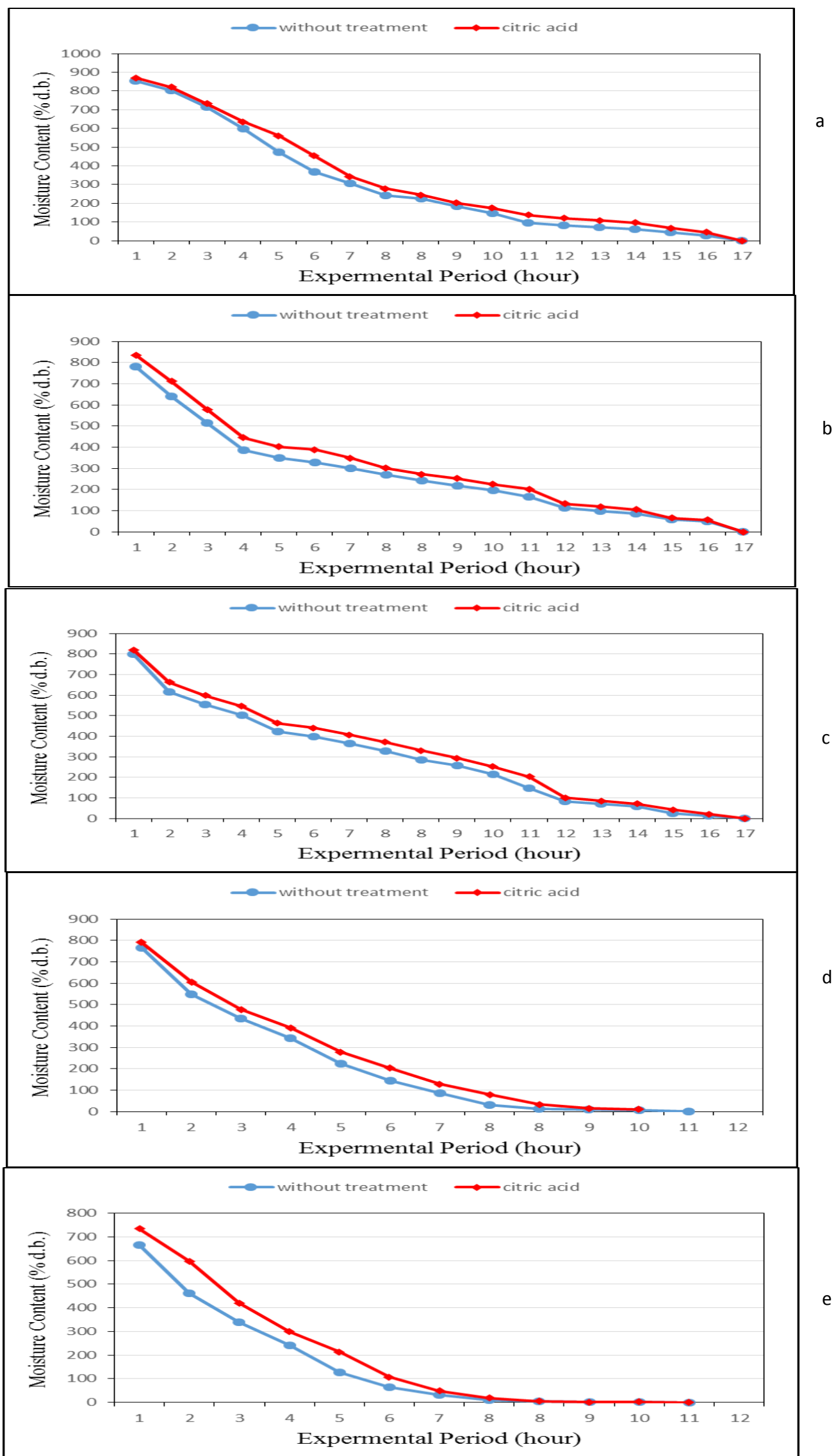

a: half fruit, b: quarter fruit, c: strips $7 \mathrm{~mm}$, d: strips $5 \mathrm{~mm}$ e: strips $3 \mathrm{~mm}$

Fig. (7): The moisture content of fruit tomato at different sizes for sun drying system during experimental period. 
Table (6): The constants $\mathrm{a}, \mathrm{b}$ and coefficient of determination for moisture content at the different tomato fruit sizes and the different pre-treatment before drying.

\begin{tabular}{|l|c|c|c|c|c|c|}
\hline \multirow{2}{*}{$\begin{array}{l}\text { Tomato } \\
\text { fruit size }\end{array}$} & \multicolumn{3}{|c|}{ Without treatment } & \multicolumn{3}{c|}{ Citric acid 2\% treatment } \\
\cline { 2 - 3 } & \multicolumn{2}{|c|}{ Constants } & \multirow{2}{*}{$\mathrm{R}^{2}$} & \multicolumn{2}{c|}{ Constants } & \multirow{2}{*}{$\mathrm{R}^{2}$} \\
\cline { 2 - 3 } & $\mathrm{a}$ & $\mathrm{b}$ & & $\mathrm{a}$ & $\mathrm{B}$ & \\
\hline Half & 987.58 & -343.22 & 0.963 & 1019.42 & -341.95 & 0.956 \\
\hline Quarter & 790.21 & -257.99 & 0.990 & 870.23 & -279.46 & 0.988 \\
\hline $7 \mathrm{~mm}$ & 856.56 & -281.34 & 0.962 & 902.24 & -287.51 & 0.944 \\
\hline $5 \mathrm{~mm}$ & 770.82 & -332.70 & 0.983 & 831.89 & -351.00 & 0.989 \\
\hline $3 \mathrm{~mm}$ & 650.13 & -297.55 & 0.974 & 771.13 & -344.94 & 0.976 \\
\hline
\end{tabular}

\subsubsection{Oven drying system:}

Fig. (8) shows the moisture content of fruit tomato that dried under oven drying system at different chemical treatments (citric acid $2 \%$ and without treatment) and different fruit tomato sizes (half fruit, quarter fruit, fruit strips of $7 \mathrm{~mm}$, fruit strips of $5 \mathrm{~mm}$ and fruit strips of $3 \mathrm{~mm}$ ) during experimental period. The results indicate that the moisture content of fruit tomato decreases with increasing drying period for all drying systems. It could be seen that the moisture content of tomato decreased from 834.43 to 1.77 and 798.62 to $5.51 \%$ d.b., when the drying period increased from 1 to 11 hours for the tomato treated with citric acid $2 \%$ before drying and without treatment, respectively, for half fruit tomato size. It decreased from 765.32 to 12.51 and 839.32 to $6.15 \%$ d.b., when the drying period increased from 1 to 8 hours for the tomato treated with citric acid $2 \%$ before drying and without treatment, respectively, for quarter fruit tomato size. It decreased from 735.90 to 4.42 and 800.02 to $7.33 \%$ d.b., when the drying period increased from 1 to 4 hours for the tomato treated with citric acid $2 \%$ before drying and without treatment, respectively, for fruit strips of $7 \mathrm{~mm}$ size. It decreased from 643.22 to 8.55 and 661.44 to $11.50 \%$ d.b., when the drying period increased from 1 to 4 hours for the tomato treated with citric acid $2 \%$ before drying and without treatment, respectively, for fruit strips of $5 \mathrm{~mm}$ size. It decreased from 498.47 to 8.39 and 489.99 to $5.48 \%$ d.b., when the drying period increased from 1 to 3 hours for the tomato treated with citric acid $2 \%$ before drying and without treatment, respectively, for fruit strips of $3 \mathrm{~mm}$ size. These results were in agreement with those obtained by Khater et al. (2019).

The results also indicate that the moisture content of fruit tomato for fruit treated by citric acid $2 \%$ before drying higher than those the fruit without treatment. It could be seen that the moisture content of fruit tomato was 834.43 and 798.62, 765.32 and 839.32, 735.90 and 800.02, 643.22 and 661.44 and 498.47 and $489.99 \%$ d.b. for the untreated tomatoes and for the treated with citric acid $2 \%$ for half fruit, quarter fruit, fruit strips of $7 \mathrm{~mm}$, fruit strips of $5 \mathrm{~mm}$ and fruit strips of $3 \mathrm{~mm}$ sizes, respectively.

Statistical analysis was carried out to obtain a relationship between the moisture content of fruit tomato of tomato fruit dried on oven drying system as dependent variable and different pretreatment before drying, tomato fruit sizes and experimental period as independent variables. The best fit for this relationship is presented in the following equation. The constants of these equations and coefficient of determination are listed in table (7).

$$
M C=a+b \ln t
$$




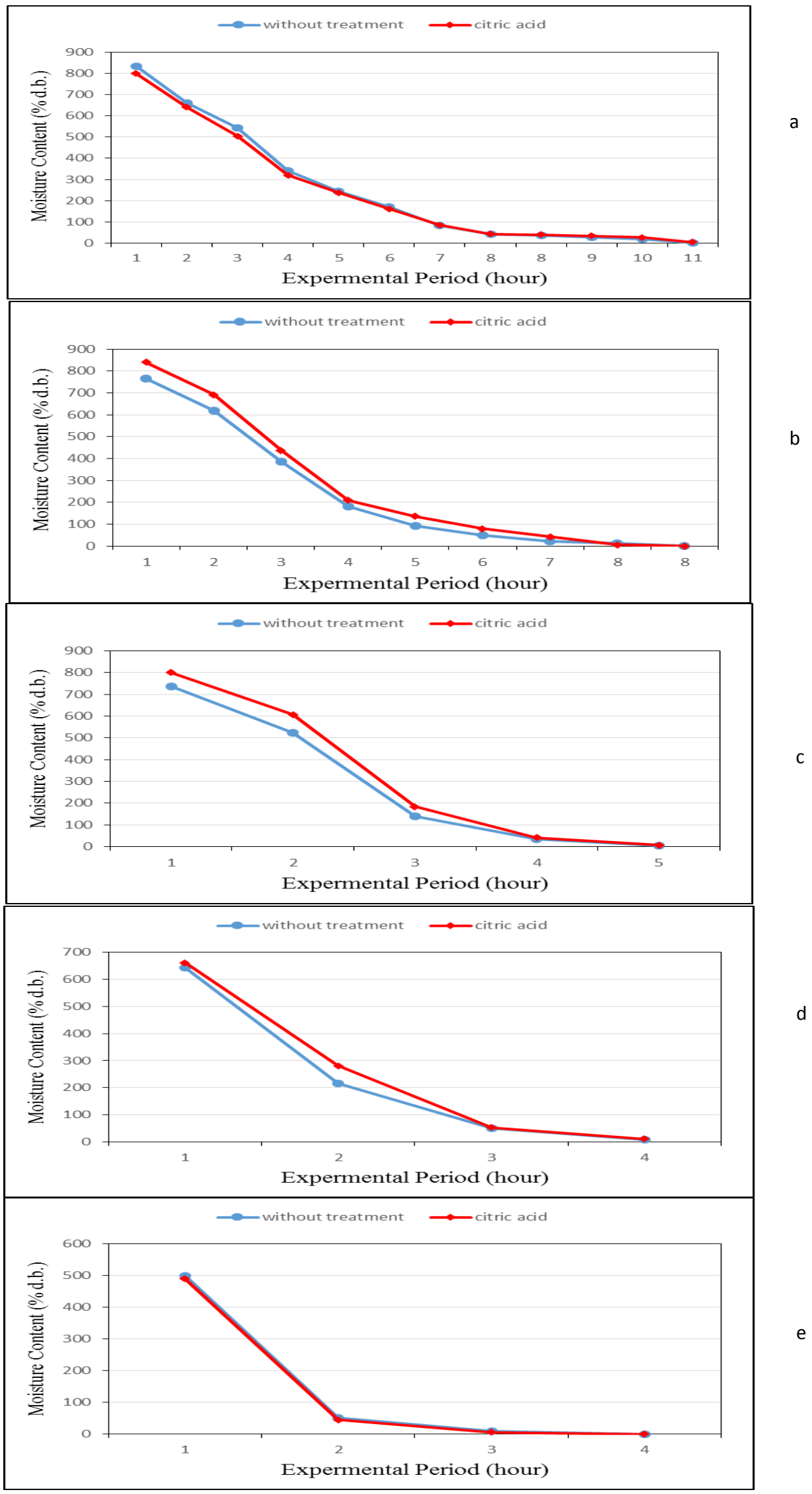

a: half fruit, b: quarter fruit, c: strips $7 \mathrm{~mm}$, d: strips $5 \mathrm{~mm}$ e: strips $3 \mathrm{~mm}$

Fig. (8): The moisture content of fruit tomato at different sizes for sun drying system during experimental period. 
Table (7): The constants $a, b$ and coefficient of determination for moisture content at the different tomato fruit sizes and the different pre-treatment before drying.

\begin{tabular}{|l|c|c|c|c|c|c|}
\hline \multirow{2}{*}{$\begin{array}{l}\text { Tomato } \\
\text { fruit size }\end{array}$} & \multicolumn{3}{|c|}{ Without treatment } & \multicolumn{3}{c|}{ Citric acid 2\% treatment } \\
\cline { 2 - 3 } & \multicolumn{2}{|c|}{ Constants } & \multirow{2}{*}{$\mathrm{R}^{2}$} & \multicolumn{2}{c|}{ Constants } & \multirow{2}{*}{$\mathrm{R}^{2}$} \\
\cline { 2 - 3 } \cline { 5 - 7 } & $\mathrm{A}$ & $\mathrm{b}$ & & $\mathrm{a}$ & $\mathrm{b}$ & \\
\hline Half & 869.51 & -371.31 & 0.973 & 827.37 & -352.94 & 0.973 \\
\hline Quarter & 805.19 & -407.34 & 0.963 & 890.56 & -441.88 & 0.967 \\
\hline $7 \mathrm{~mm}$ & 765.17 & -498.70 & 0.951 & 848.53 & -543.53 & 0.942 \\
\hline $5 \mathrm{~mm}$ & 605.15 & -472.80 & 0.961 & 640.87 & -489.81 & 0.978 \\
\hline $3 \mathrm{~mm}$ & 465.30 & -467.53 & 0.916 & 546.52 & -462.66 & 0.913 \\
\hline
\end{tabular}

3.4. Drying rate:

\subsubsection{Sun drying system:}

Fig. (9) shows the drying rate of fruit tomato that dried under sun drying system at different chemical treatments (citric acid 2\% and without treatment) and different fruit tomato sizes (half fruit, quarter fruit, fruit strips of $7 \mathrm{~mm}$, fruit strips of $5 \mathrm{~mm}$ and fruit strips of $3 \mathrm{~mm}$ ) during experimental period. The results indicate that the drying rate of fruit tomato decreases with increasing drying period for all drying systems. It could be seen that the drying rate of tomato decreased from 85.41 to 0.001 and 86.42 to $0.001 \mathrm{~kg}_{\text {water }} / \mathrm{kg}_{\text {dry base. }} \mathrm{hr}$, when the drying period increased from 1 to 10 days for the tomato treated with citric acid $2 \%$ before drying and without treatment, respectively, for half fruit tomato size. It decreased from 104.93 to 0.001 and 107.67 to $0.001 \mathrm{~kg}_{\text {water }} / \mathrm{kg}_{\text {dry base. }} \mathrm{hr}$, when the drying period increased from 1 to 7 days for the tomato treated with citric acid $2 \%$ before drying and without treatment, respectively, for quarter fruit tomato size. It decreased from 174.47 to 0.002 and 177.65 to $0.004 \mathrm{~kg}_{\text {water }} / \mathrm{kg}_{\text {dry base. }} \mathrm{hr}$, when the drying period increased from 1 to 4 days for the tomato treated with citric acid $2 \%$ before drying and without treatment, respectively, for fruit strips of $7 \mathrm{~mm}$ size.

The drying rate decreased from 140.23 to 0.00 and 146.70 to $0.003 \mathrm{~kg}_{\text {water }} / \mathrm{kg}_{\text {dry base. }} \mathrm{hr}$, when the drying period increased from 1 to 4 days for the tomato treated with citric acid $2 \%$ before drying and without treatment, respectively, for fruit strips of $5 \mathrm{~mm}$ size. It decreased from 137.67 to 0.002 and 141.72 to $0.004 \mathrm{~kg}_{\text {water }} / \mathrm{kg}_{\text {dry base. }}$ hr., when the drying period increased from 1 to 4 days for the tomato treated with citric acid $2 \%$ before drying and without treatment, respectively, for fruit strips of $3 \mathrm{~mm}$ size.

The results also indicate that the drying rate of fruit tomato for fruit treated by citric acid $2 \%$ before drying higher than those the fruit without treatment. It could be seen that the drying rate of fruit tomato was 85.41 and 86.42, 104.93 and 107.67, 174.47 and 177.65, 140.23 and 146.70 and 137.67 and $141.72 \mathrm{~kg}_{\text {water }} / \mathrm{kg}_{\text {dry base. }} \mathrm{hr}$ for the untreated tomatoes and for the treated with citric acid $2 \%$ for half fruit, quarter fruit, fruit strips of $7 \mathrm{~mm}$, fruit strips of $5 \mathrm{~mm}$ and fruit strips of $3 \mathrm{~mm}$ sizes, respectively.

Statistical analysis was carried out to obtain a relationship between the drying rate of fruit tomato of tomato fruit dried on sun drying system as dependent variable and different pretreatment before drying, tomato fruit sizes and experimental period as independent variables. The best fit for this relationship is presented in the following equation. The constants of these equations and coefficient of determination are listed in table (8).

$$
D R=a+b \operatorname{lnt}
$$




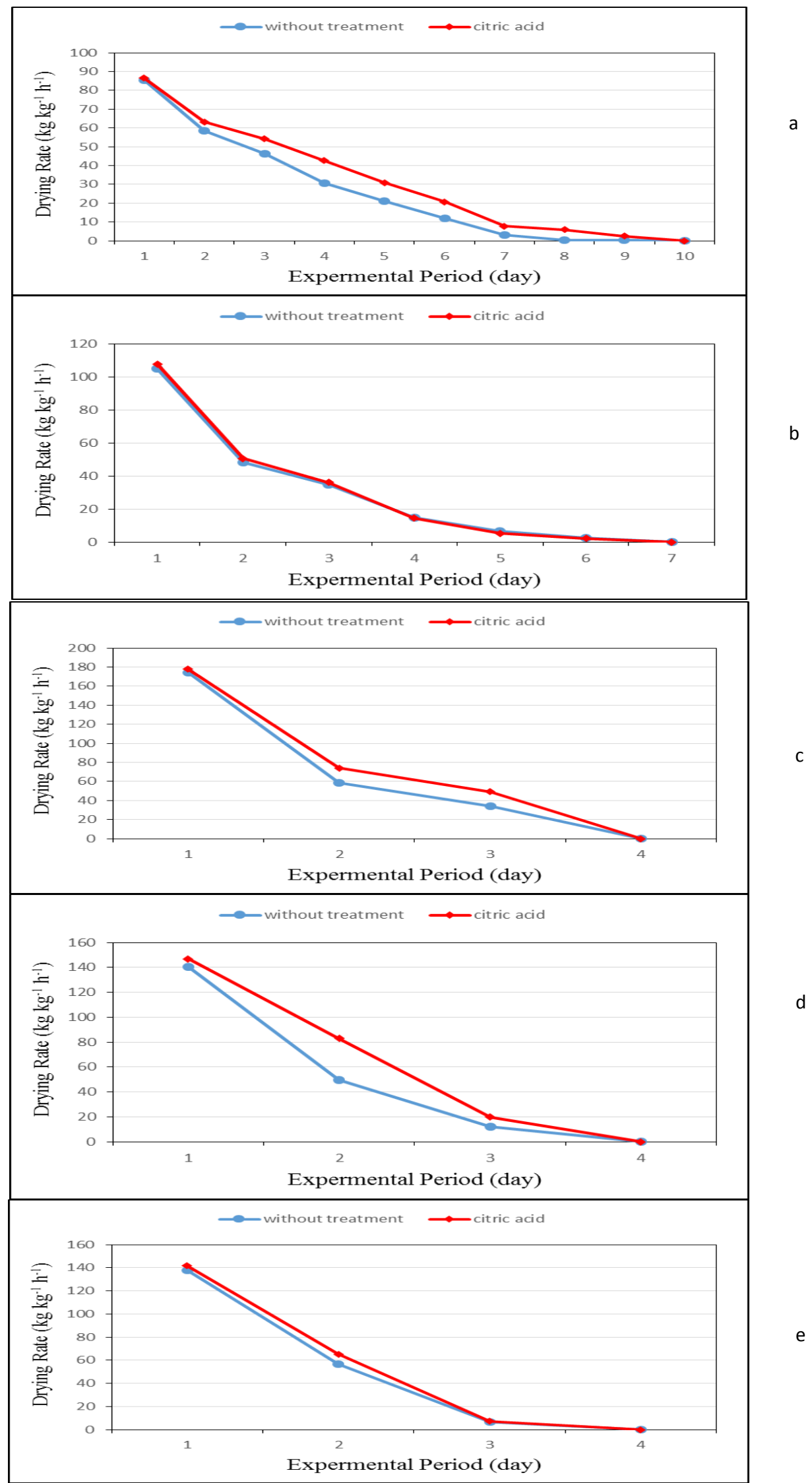

a: half fruit, b: quarter fruit, c: strips $7 \mathrm{~mm}$, d: strips $5 \mathrm{~mm}$ e: strips $3 \mathrm{~mm}$

Fig. (9): The drying rate of fruit tomato at different sizes for sun drying system during experimental period. 
Table (8): The constants $a, b$ and coefficient of determination for drying rate at the different tomato fruit sizes and the different pre-treatment before drying.

\begin{tabular}{|l|c|c|c|c|c|c|}
\hline \multirow{2}{*}{$\begin{array}{l}\text { Tomato } \\
\text { fruit size }\end{array}$} & \multicolumn{3}{|c|}{ Without treatment } & \multicolumn{3}{c|}{ Citric acid 2\% treatment } \\
\cline { 2 - 3 } & \multicolumn{2}{|c|}{ Constants } & \multirow{2}{*}{$\mathrm{R}^{2}$} & \multicolumn{2}{c|}{ Constants } & \multirow{2}{*}{$\mathrm{R}^{2}$} \\
\cline { 2 - 3 } \cline { 5 - 7 } & $\mathrm{a}$ & $\mathrm{b}$ & & $\mathrm{a}$ & $\mathrm{b}$ & \\
\hline Half & 85.89 & -39.79 & 0.988 & 91.54 & -39.82 & 0.978 \\
\hline Quarter & 95.47 & -53.61 & 0.961 & 98.52 & -55.55 & 0.962 \\
\hline $7 \mathrm{~mm}$ & 165.06 & -123.81 & 0.966 & 173.19 & -123.30 & 0.979 \\
\hline $5 \mathrm{~mm}$ & 133.04 & -104.00 & 0.971 & 149.48 & -109.72 & 0.986 \\
\hline $3 \mathrm{~mm}$ & 133.06 & -104.36 & 0.974 & 139.25 & -107.95 & 0.977 \\
\hline
\end{tabular}

\subsubsection{Solar drying system:}

Fig. (10) shows the drying rate of fruit tomato that dried under solar drying system at different chemical treatments (citric acid $2 \%$ and without treatment) and different fruit tomato sizes (half fruit, quarter fruit, fruit strips of $7 \mathrm{~mm}$, fruit strips of $5 \mathrm{~mm}$ and fruit strips of $3 \mathrm{~mm}$ ) during experimental period. The results indicate that the drying rate of fruit tomato decreases with increasing drying period for all drying systems. It could be seen that the drying rate of tomato decreased from 48.63 to 0.00 and 48.70 to $0.001 \mathrm{~kg}_{\text {water }} / \mathrm{kg}_{\text {dry base. }} \mathrm{hr}$, when the drying period increased from 1 to 17 hours for the tomato treated with citric acid $2 \%$ before drying and without treatment, respectively, for half fruit tomato size. It decreased from 43.05 to 0.002 and 45.86 to $0.004 \mathrm{~kg}_{\text {water }} / \mathrm{kg}_{\text {dry base }} . \mathrm{hr}$, when the drying period increased from 1 to 17 hours for the tomato treated with citric acid $2 \%$ before drying and without treatment, respectively, for quarter fruit tomato size. It decreased from 46.24 to 0.002 and 46.94 to $0.00 \mathrm{~kg}_{\text {water }} / \mathrm{kg}_{\text {dry base. }} \mathrm{hr}$, when the drying period increased from 1 to 17 hours for the tomato treated with citric acid $2 \%$ before drying and without treatment, respectively, for fruit strips of $7 \mathrm{~mm}$ size. It decreased from 63.71 to 2.25 and 71.03 to $0.001 \mathrm{~kg}_{\text {water }} / \mathrm{kg}_{\text {dry base }}$.hr, when the drying period increased from 1 to 11 hours for the tomato treated with citric acid $2 \%$ before drying and without treatment, respectively, for fruit strips of $5 \mathrm{~mm}$ size. It decreased from 60.10 to 0.002 and 66.66 to 0.004 $\mathrm{kg}_{\text {water }} / \mathrm{kg}_{\text {dry base. }} \mathrm{hr}$, when the drying period increased from 1 to 11 hours for the tomato treated with citric acid $2 \%$ before drying and without treatment, respectively, for fruit strips of $3 \mathrm{~mm}$ size.

The results also indicate that the drying rate of fruit tomato for fruit treated by citric acid $2 \%$ before drying higher than those the fruit without treatment. It could be seen that the drying rate of fruit tomato was 4863 and 48.70, 43.05 and 45.86, 46.24 and 46.94, 63.71 and 71.03 and 60.10 and $66.66 \mathrm{~kg}_{\text {water }} / \mathrm{kg}_{\text {dry base. }} \mathrm{hr}$ for the untreated tomatoes and for the treated with citric acid $2 \%$ for half fruit, quarter fruit, fruit strips of $7 \mathrm{~mm}$, fruit strips of $5 \mathrm{~mm}$ and fruit strips of $3 \mathrm{~mm}$ sizes, respectively.

Statistical analysis was carried out to obtain a relationship between the drying rate of fruit tomato of tomato fruit dried on solar drying system as dependent variable and different pretreatment before drying, tomato fruit sizes and experimental period as independent variables. The best fit for this relationship is presented in the following equation. The constants of these equations and coefficient of determination are listed in table (9).

$$
D R=a+b \ln t
$$




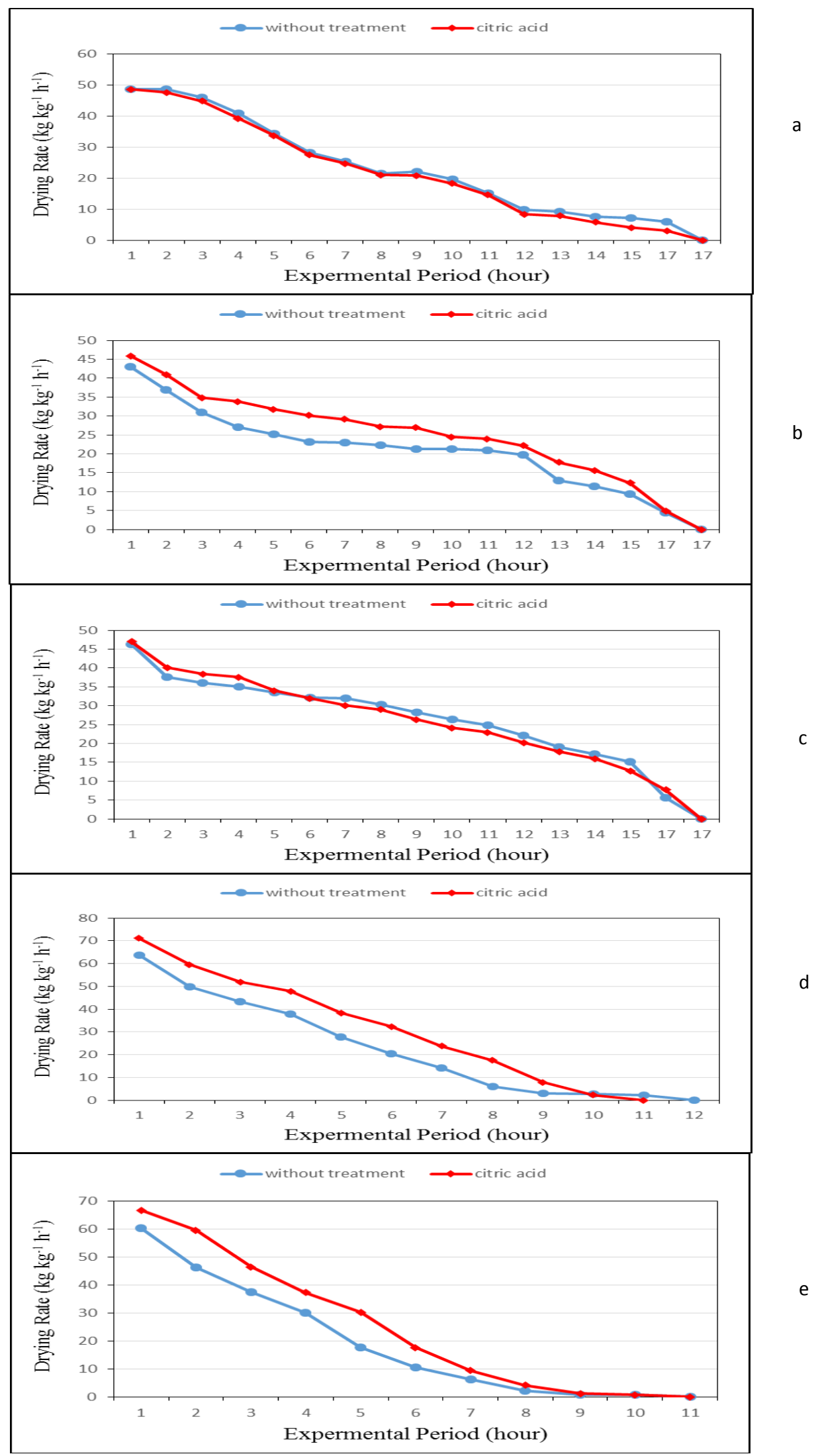

a: half fruit, b: quarter fruit, c: strips $7 \mathrm{~mm}$, d: strips $5 \mathrm{~mm}$ e: strips $3 \mathrm{~mm}$

Fig. (10): The drying rate of fruit tomato at different sizes for sun drying system during experimental period. 
Table (9): The constants $a, b$ and coefficient of determination for drying rate at the different tomato fruit sizes and the different pre-treatment before drying.

\begin{tabular}{|l|c|c|c|c|c|c|}
\hline \multirow{2}{*}{$\begin{array}{l}\text { Tomato } \\
\text { fruit size }\end{array}$} & \multicolumn{3}{|c|}{ Without treatment } & \multicolumn{3}{c|}{ Citric acid 2\% treatment } \\
\cline { 2 - 3 } & \multicolumn{2}{|c|}{ Constants } & \multirow{2}{*}{$\mathrm{R}^{2}$} & \multicolumn{2}{c|}{ Constants } & \multirow{2}{*}{$\mathrm{R}^{2}$} \\
\cline { 2 - 3 } & $\mathrm{a}$ & $\mathrm{b}$ & & $\mathrm{a}$ & $\mathrm{b}$ & \\
\hline Half & 60.67 & -19.15 & 0.914 & 60.31 & -19.59 & 0.920 \\
\hline Quarter & 45.99 & -12.81 & 0.867 & 51.58 & 013.59 & 0.813 \\
\hline $7 \mathrm{~mm}$ & 51.45 & -12.93 & 0.798 & 53.62 & -14.21 & 0.835 \\
\hline $5 \mathrm{~mm}$ & 69.59 & -28.19 & 0.966 & 81.11 & -30.85 & 0.922 \\
\hline $3 \mathrm{~mm}$ & 63.75 & -27.98 & 0.975 & 76.21 & -32.31 & 0.953 \\
\hline
\end{tabular}

\subsubsection{Oven drying system:}

Fig. (11) shows the drying rate of fruit tomato that dried under oven drying system at different chemical treatments (citric acid 2\% and without treatment) and different fruit tomato sizes (half fruit, quarter fruit, fruit strips of $7 \mathrm{~mm}$, fruit strips of $5 \mathrm{~mm}$ and fruit strips of $3 \mathrm{~mm}$ ) during experimental period. The results indicate that the drying rate of fruit tomato decreases with increasing drying period for all drying systems. It could be seen that the drying rate of tomato decreased from 72.10 to 2.80 and 75.70 to $3.25 \mathrm{~kg}_{\text {water }} / \mathrm{kg}_{\text {dry }}$ base.hr, when the drying period increased from 1 to 11 hours for the tomato treated with citric acid $2 \%$ before drying and without treatment, respectively, for half fruit tomato size. It decreased from 94.10 to 0.002 and 104.15 to $0.004 \mathrm{~kg}_{\text {water }} / \mathrm{kg}_{\text {dry base. }} \mathrm{hr}$, when the drying period increased from 1 to 8 hours for the tomato treated with citric acid $2 \%$ before drying and without treatment, respectively, for quarter fruit tomato size. It decreased from 146.30 to 0.003 and 158.54 to $0.003 \mathrm{~kg}_{\text {water }} / \mathrm{kg}_{\text {dry base. }} . \mathrm{hr}$, when the drying period increased from 1 to 4 hours for the tomato treated with citric acid $2 \%$ before drying and without treatment, respectively, for fruit strips of $7 \mathrm{~mm}$ size. It decreased from 158.70 to 0.001 and 162.48 to $0.002 \mathrm{~kg}_{\text {water }} / \mathrm{kg}_{\text {dry base. }} \mathrm{hr}$, when the drying period increased from 1 to 4 hours for the tomato treated with citric acid 2\% before drying and without treatment, respectively, for fruit strips of $5 \mathrm{~mm}$ size. It decreased from 161.50 to 0.002 and 163.36 to 0.004 $\mathrm{kg}_{\text {water }} / \mathrm{kg}_{\text {dry base. }}$ hr, when the drying period increased from 1 to 3 hours for the tomato treated with citric acid $2 \%$ before drying and without treatment, respectively, for fruit strips of $3 \mathrm{~mm}$ size.

The results also indicate that the drying rate of fruit tomato for fruit treated by citric acid $2 \%$ before drying higher than those the fruit without treatment. It could be seen that the drying rate of fruit tomato was 72.10 and 75.70, 94.10 and 104.15, 146.30 and 158.54, 158.70 and 162.48 and 161.50 and $163.36 \mathrm{~kg}_{\text {water }} / \mathrm{kg}_{\text {dry base. }} \mathrm{hr}$ for the untreated tomatoes and for the treated with citric acid $2 \%$ for half fruit, quarter fruit, fruit strips of $7 \mathrm{~mm}$, fruit strips of $5 \mathrm{~mm}$ and fruit strips of $3 \mathrm{~mm}$ sizes, respectively.

Statistical analysis was carried out to obtain a relationship between the drying rate of fruit tomato of tomato fruit dried on oven drying system as dependent variable and different pretreatment before drying, tomato fruit sizes and experimental period as independent variables. The best fit for this relationship is presented in the following equation. The constants of these equations and coefficient of determination are listed in table (10).

$$
D R=a+b \ln t
$$




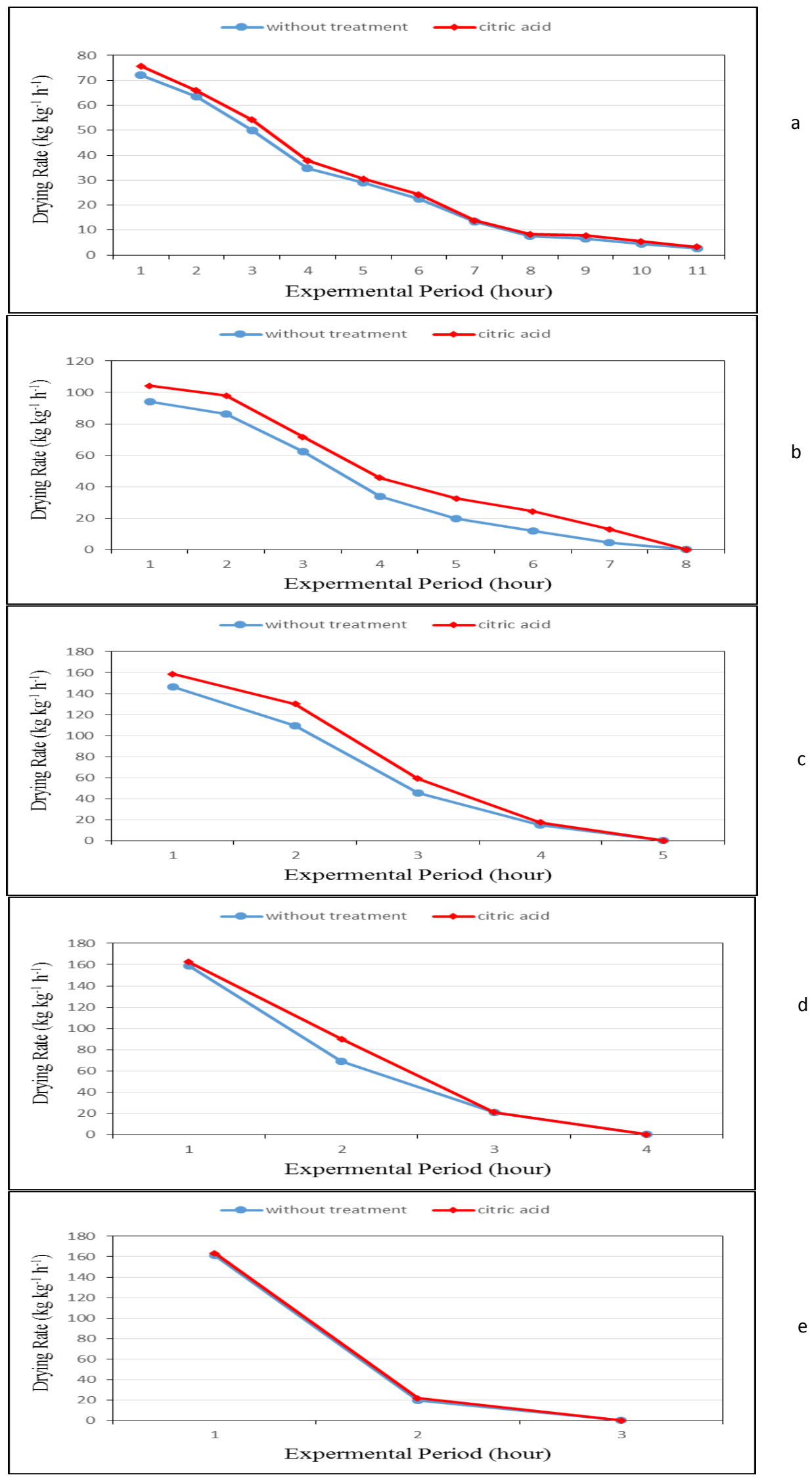

a: half fruit, b: quarter fruit, c: strips $7 \mathrm{~mm}$, d: strips $5 \mathrm{~mm}$ e: strips $3 \mathrm{~mm}$

Fig. (11): The drying rate of fruit tomato at different sizes for sun drying system during experimental period. 
Table (10): The constants $a, b$ and coefficient of determination for drying rate at the different tomato fruit sizes and the different pre-treatment before drying.

\begin{tabular}{|l|c|c|c|c|c|c|}
\hline \multirow{2}{*}{$\begin{array}{l}\text { Tomato } \\
\text { fruit size }\end{array}$} & \multicolumn{3}{|c|}{ Without treatment } & \multicolumn{3}{c|}{ Citric acid 2\% treatment } \\
\cline { 2 - 3 } & \multicolumn{2}{|c|}{ Constants } & \multirow{2}{*}{$\mathrm{R}^{2}$} & \multicolumn{2}{c|}{ Constants } & \multirow{2}{*}{$\mathrm{R}^{2}$} \\
\cline { 2 - 3 } \cline { 5 - 7 } & $\mathrm{a}$ & $\mathrm{b}$ & & $\mathrm{a}$ & $\mathrm{b}$ & \\
\hline Half & 79.62 & -32.53 & 0.972 & 83.72 & -33.93 & 0.969 \\
\hline Quarter & 107.03 & -51.29 & 0.941 & 119.41 & -53.39 & 0.936 \\
\hline $7 \mathrm{~mm}$ & 155.91 & -96.81 & 0.962 & 174.00 & -105.51 & 0.937 \\
\hline $5 \mathrm{~mm}$ & 155.04 & -116.94 & 0.992 & 164.97 & -121.69 & 0.987 \\
\hline $3 \mathrm{~mm}$ & 154.24 & -154.87 & 0.939 & 151.72 & -153.16 & 0.933 \\
\hline
\end{tabular}

3.5. Sugar, ash and lycopene contents:

Table (11) shows sugar, ash and lycopene contents of fruit tomato that dried under oven drying system at different chemical treatments (citric acid 2\% and without treatment) and different fruit tomato sizes (half fruit, quarter fruit, fruit strips of $7 \mathrm{~mm}$, fruit strips of $5 \mathrm{~mm}$ and fruit strips of $3 \mathrm{~mm}$ ) at the end of experimental period. The results indicate that the sugar, ash and lycopene contents of fruit tomato for fruit treated by citric acid $2 \%$ before drying higher than those the fruit without treatment. It could be seen that the sugar content ranged from 2.07 to 2.42 and 2.27 to $2.74 \%$ for the untreated tomatoes and for the treated with citric acid $2 \%$, respectively, for all treatment size. The ash content ranged from 2.33 to 2.68 and 2.34 to 2.74 $\%$, respectively, for the untreated tomatoes and for the treated with citric acid $2 \%$ for all treatment size and the lycopene content ranged from 3.21 to 3.80 and 3.36 to $3.99 \mathrm{mg} / 100 \mathrm{~g}$, respectively, for the untreated tomatoes and for the treated with citric acid $2 \%$ for all treatment size. The results also indicate that the sugar, ash and lycopene contents of fruit tomato for fruit dried in solar drying system higher than those the fruits dried in sun and oven drying systems.

Table (11) shows sugar, ash and lycopene contents of dried tomato.

\begin{tabular}{|l|l|l|l|l|l|l|l|l|l|l|}
\hline \multirow{2}{*}{$\begin{array}{l}\text { Tomato } \\
\text { size }\end{array}$} & $\begin{array}{l}\text { Chemical } \\
\text { treatment }\end{array}$ & \multicolumn{3}{|c|}{ Sugar, \% } & \multicolumn{4}{|c|}{ Ash, \% } & \multicolumn{3}{c|}{ Lycopene, mg/ 100g } \\
\cline { 2 - 11 } & Sun & Solar & Oven & Sun & Solar & Oven & Sun & Solar & Oven \\
\hline \multirow{2}{*}{ Half } & $\mathrm{W}$ & 2.34 & 2.41 & 2.09 & 2.61 & 2.60 & 2.35 & 3.63 & 3.78 & 3.21 \\
\cline { 2 - 12 } & $\mathrm{C}$ & 2.57 & 2.72 & 2.28 & 2.65 & 2.67 & 2.34 & 3.89 & 3.97 & 3.36 \\
\hline \multirow{3}{*}{ Quarter } & $\mathrm{W}$ & 2.31 & 2.29 & 2.09 & 2.62 & 2.67 & 2.34 & 3.62 & 3.75 & 3.28 \\
\cline { 2 - 11 } & $\mathrm{C}$ & 2.50 & 2.67 & 2.27 & 2.62 & 2.74 & 2.35 & 3.77 & 3.99 & 3.36 \\
\hline \multirow{3}{*}{$7 \mathrm{~mm}$} & $\mathrm{~W}$ & 2.35 & 2.40 & 2.07 & 2.59 & 2.68 & 2.35 & 3.59 & 3.78 & 3.30 \\
\cline { 2 - 11 } & $\mathrm{C}$ & 2.51 & 2.73 & 2.29 & 2.64 & 2.65 & 2.35 & 3.85 & 3.95 & 3.37 \\
\hline \multirow{3}{*}{$5 \mathrm{~mm}$} & $\mathrm{~W}$ & 2.36 & 2.42 & 2.11 & 2.60 & 2.61 & 2.39 & 3.63 & 3.80 & 3.30 \\
\cline { 2 - 11 } & $\mathrm{C}$ & 2.58 & 2.74 & 2.28 & 2.66 & 2.73 & 2.41 & 3.91 & 3.99 & 3.37 \\
\hline \multirow{3}{*}{$3 \mathrm{~mm}$} & $\mathrm{~W}$ & 2.36 & 2.40 & 2.10 & 2.62 & 2.65 & 2.33 & 3.62 & 3.79 & 3.31 \\
\cline { 2 - 10 } & $\mathrm{C}$ & 2.57 & 2.72 & 2.31 & 2.67 & 2.74 & 2.42 & 3.89 & 3.98 & 3.36 \\
\hline
\end{tabular}

$\mathrm{W}$ is the untreated tomatoes $\quad \mathrm{C}$ is the fruit treated by citric acid $2 \%$ before drying

\section{CONCLUSION}

Tomatoes were treated before drying, cut into different size, dried successively three systems of drying (sun, solar and oven drying). Weight loss, moisture content and drying rate were evaluated during the drying period. It is concluded that the accumulated weight loss of fruit tomato for fruit treated with citric acid $2 \%$ before drying was lower than those the fruit without 
treatment. The accumulated weight loss of fruit tomato ranged from 2.00 to $94.73 \%$ for all treatment. The highest values moisture content of fruits tomato were 870.08, 839.32, 819.15, 790.73 and $734.88 \%$ d.b. for half fruit, quarter fruit, fruit strips of $7 \mathrm{~mm}$, fruit strips of $5 \mathrm{~mm}$ and fruit strips of $3 \mathrm{~mm}$ sizes, respectively. The drying rate of fruits tomato ranged from 0.00 to $177.65,0.00$ to 71.03 and 0.001 to $163.36 \mathrm{~kg}_{\text {water }} / \mathrm{kg}_{\text {dry base. }}$ hr for sun drying, solar drying and oven drying systems. The highest value of drying rate of fruits tomato was $177.65 \mathrm{~kg}$ water $/ \mathrm{kg}_{\text {dry }}$ base.hr was found for $7 \mathrm{~mm}$ fruit strips with citric acid $2 \%$ before drying for sun drying system. The sugar, ash and lycopene contents of fruit tomato for fruit treated by citric acid $2 \%$ before drying higher than those the fruit without treatment.

\section{REFERENCES}

Abd El-Haq O.M., Khater E.G., Bahnasawy A.H. and El-Ghobashy H.M.T. (2020). Effect of Distillation Methods on Essential Oil Yield and Composition of Basil Dried by Different Drying Systems. Annals of Agric. Sci., Moshtohor, 52 (2): 247-260.

Abd El-Haq O.M., Khater E.G., Bahnasawy A.H. and El-Ghobashy H.M.T. (2020). Effect of Drying Systems on the Parameters and Quality of Dried Basil. Annals of Agric. Sci., Moshtohor, 52 (2): 261-272.

ASAE Standards (1998). ASAE S353 DEC97. Moisture measurement-meat and products. Adopted and published by ASAE 1998, St. Josebh, MI: ASAE. $45^{\text {th }}$ Edition P552.

Bremmer, J. M. and Mulvaney C.S. (1982). Nitrogen-total. In: Page, A.L., Miller, R.H., Keeney, D.R. (Eds.), Methods of Soil Analysis, Part 2. Chemical and Microbiological Properties, second ed., Agronomy series No. 9 ASA, SSSA, Madison, WI, pp. 595-624.

Chapman, H.D. and Partt F.P. (1961). Methods of Analysis of Soils, Plant and Water. California University, pp. 150-200.

Ekechukwu, O.V., and Norton B. (1999). Review of solar-energy drying systems II: an overview of solar drying technology. Energy Conversion and Management, 40(6): 615655 .

Jayathunge, K.G., Kapilarathne R.A., Thilakarathne B.M., Fernando M.D., Palipane K.B. and Prasanna P.H. (2012). Development of a methodology for production of dehydrated tomato powder and study the acceptability of the product. Journal of Agricultural Technology, 8(2): 765-773.

Khater, E.G., Bahnasawy A.H. (2017). Basil Drying Performance and Quality under Different Drying Systems. $2^{\text {nd }}$ International Sino-Egyptian Congress on Agriculture, Veterinary Sciences and Engineering (2 ${ }^{\text {nd }}$ ISEC-AVE), 7 - 10 October, 2017, Egypt.

Khater, E.G., Bahnasawy A.H., Hamouda R.M. (2019). Dehydration of chamomile flowers under different drying conditions. Journal of Food Processing and Technology, 10 (7), $1-7$.

Liwicki, P.P., Vule H., Pmaranska-Lazuka E. (2002). Effect of pre-treatment on convective drying of tomatoes. Journal of food Engineering, 54, $141-146$. 
Mumba, J. (1995). Development of a photovoltaic powered forced circulation grain dryer for use in the tropics. Renewable Energy, 6(7): 855-862.

Murphy, J. and Riley J.P. (1962). A modified single solution method for determination of phosphate in natural waters. Anal. Chem. Acta, 27: 31-36.

Sacilik, K., Keskin R., and Elicin A.K. (2006). Mathematical modelling of solar tunnel drying of thin layer organic tomato. Journal of Food Engineering, 73(3): 231-238.

Shahnawaz, M., Sheikh S.A., Soomro A.H., Panhwar A.A., and Khaskheli S.G. (2012). Quality characteristics of tomatoes (Lycopersicon esculentum) stored in various wrapping materials, African Journal of Food Science and Technology, 3(5): 123-128.

Vlachos, N.A., Karapantsios T.D., Balouktsis A.I., and Chassapis D. (2002). Design and testing of a new solar tray dryer. Drying Technology, 20(6): 1243-1271.

Zanoni, B., Peri C., Nani R. and Lavelli V. (1999). Oxidative heat damage of tomato halves as affected by drying. Food Research International, 31(5):395-401. 


\section{تأثير طرق التجفيف على جودة الطماطم المجففة

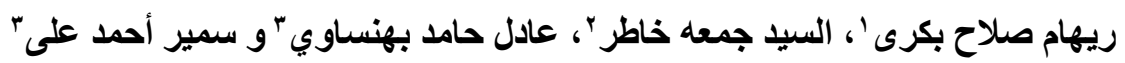 \\ ' طالبة در اسات عليا ـ قسم الهندسة الزر اعية ـ كلية الزر اعة بمشتهر - جامعة بنها ـ مصر.

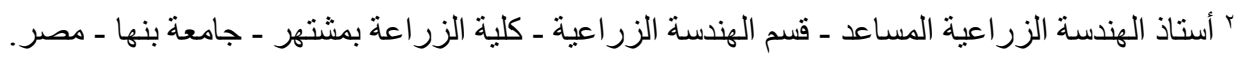

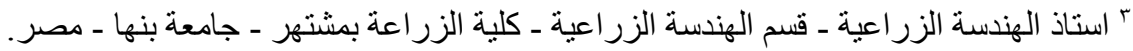

يهدف هذا البحث الى در اسة تأثثر نظم تجفيف مختلفة (شمسي طبيعي - شمسي -

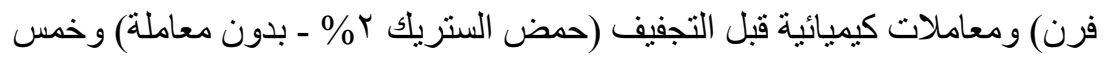

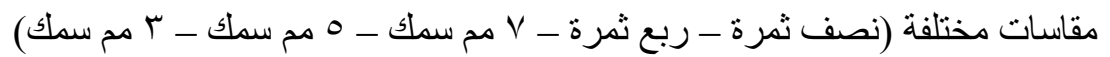
على جودة ثمار الطماطم المجففة. وتم إجراء هذه التجربة فى قسم هندسة النظم الزر اعية و الحيوية ـ كلية الزراعة بمشتهر - جامعة بنها - محافظة القليوبية. وتم تقدير كلا من الفاقد فى الوزن و المحتوى الرطوبى و معدل التجفيف. وكانت أهم النتائج

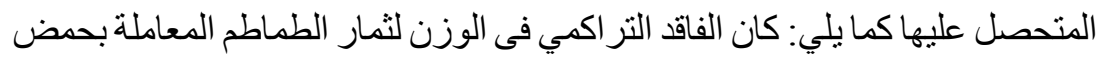
الستريك قبل التجفيف اقل من الفاقد التراكمي فى الوزن لثمار الطماطم الغير معاملة.

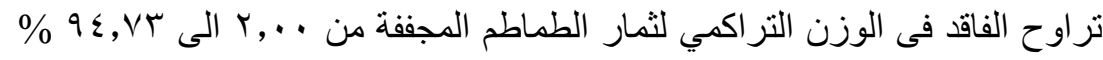

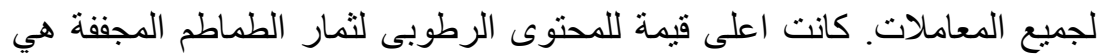

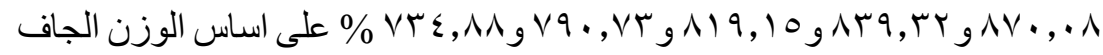

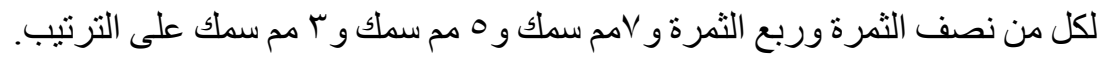

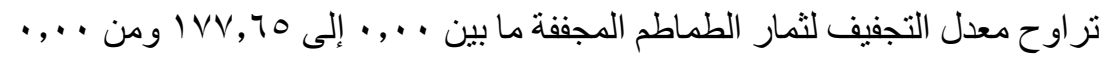

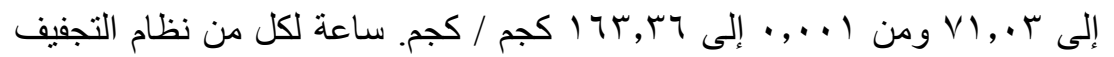
الشمسي الطبيعي ونظام التجفيف الثمسي والتجفيف فى الفرن على الترنيب. كانت

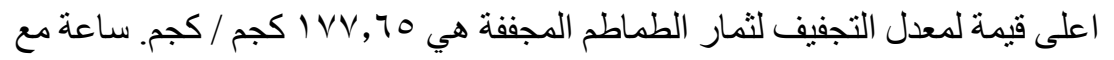
V م سمك شر ائح ثمار الطماطم المعاملة بحمض الستريك ب٪\% قبل التجفيف و المجفف فى نظام التجفيف الثمسي الطبيعي. كان محتوى الطماطم المجففة من السكر و الرماد

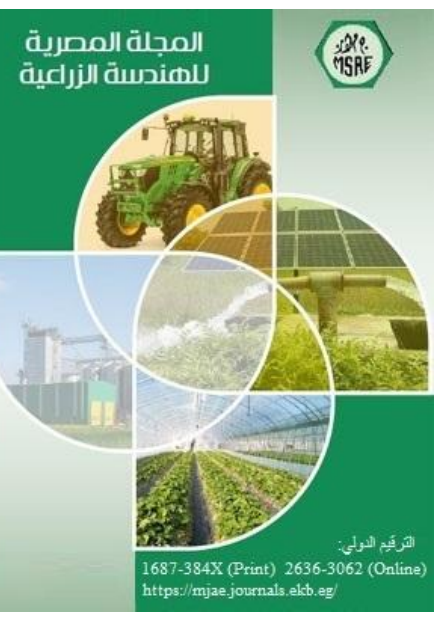

(المجلة المصرية للهندسة الزراعية

الكلمات المفتاحية:

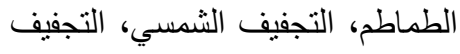
فى الفرن، الفاقد فى الوزن، المحتوى

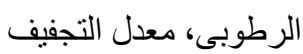

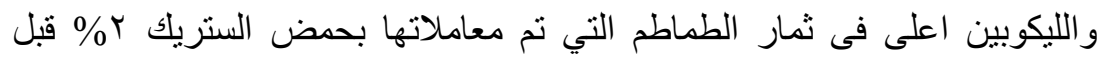
التجفيف من الثمار الغير معاملة. 